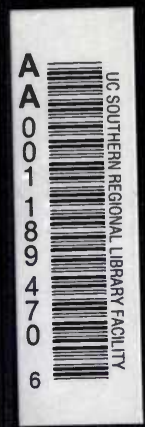









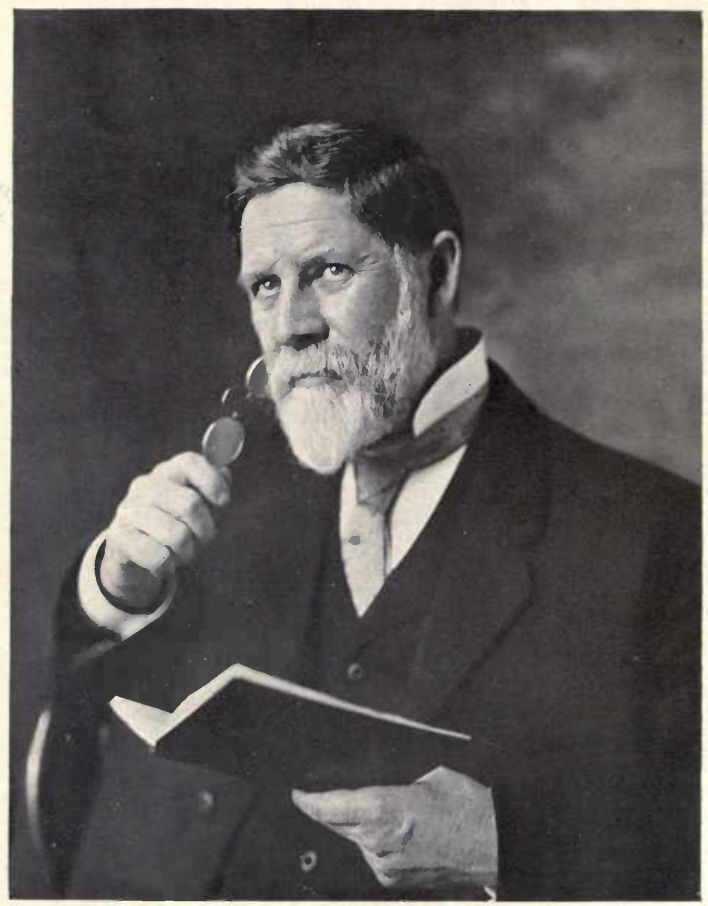

Erwin F. SMith.

Dean of American plant pathologists. 


\section{An Outline of the}

\section{History of Phytopathology}

BY

Herbert Hice Whetzel

Professor of Plant Pathology at Cornell University Ithaca, New York

With 22 Portraits

Philadelphia and London

W. B. Saunders Company

1918

\section{7}


Copyright, I9I8, by W. B. Saunders Company

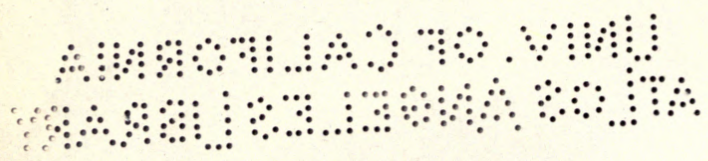

PRINTED IN AMERICA

PRESS OF

W. B. SAUNDERS COMPANY

PHILADELPHIA 

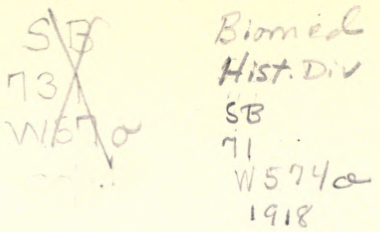

TO

THE MEMORY OF

ftason 砖. Thomas

A GREAT TEACHER AND A TRUE FRIEND THIS LITTLE VOLUME IS GRATEFULLY DEDICATED 



\section{PREFACE}

This booklet is to be regarded as in no sense a complete history of the science of plant pathology. The author has endeavored only to set forth in outline what appear to be the most outstanding features in the evolution of the science, and to indicate the proper relation thereto of the men who have chiefly shaped its progress.

A The literature upon which a complete history of plant pathology must be based is here largely brought together for the first time. It is hoped that this sketch may be elaborated later into a more complete and critical presentation of the subject.

The author desires to express his appreciation of the assistance of numerous friends and colleagues in the preparation of this book; to a number of them, and especially to Dr. Erwin F. Smith, for photographs, im$\{$ portant historic data, and a final criticism of the completed text; to Dr. L. R. Hesler and Dr. C. H. Kauffmann for critical reading of the manuscript.

H. H. WhetZeL.

Cornell University, Ithaca, N. Y.

May, IgI8. 



\section{CONTENTS}

Introduction ............................... 11

The Ancient Era (from Earliest Times to End of 5th Century A. D.):

Hebraic Period (to about 500 B. C.) ............. 14

Theophrastian Period (500 to 320 B. C.) . . . . . . . . . 14

Plinian Period (320 B. C. to 476 A. D.) . . . . . . . . 17

Summary. . . . . . . . . . . . . . . . . . 18

ThE DARK ERA (6th to 16 th Centuries Inclusive) . . . . . . . . 20

The Premodern Era $(1600$ to about 1850$) \ldots \ldots \ldots \ldots \ldots \ldots 22$

The Renaissance Period (17th Century) . . . . . . . . . 22

Summary........................... 24

The Zallingerian Period (18th Century) ............. 25

Characteristic Features. . . . . . . . . . . . . . 32

The Ungerian Period (1807 to 1853) . . . . . . . . . . . 33

Characteristic Features................ 40

The Modern Era (1853 to about 1906) . . . . . . . . . . . . . . 41

The Kühnian Period $(1853$ to 1883$) \ldots \ldots \ldots \ldots \ldots \ldots \ldots 4$

Summary........................... 57

The Millardetian Period (1883 to about 1906) ......... 58

Discovery of Bordeaux Mixture. . . . . . . . . . 58, 63

Rise and Development of Plant Pathology in America. . . . 59

Discovery of Bacterial Etiology of Certain Plant Diseases. . 61

Discovery and Establishment of Causal Relation of Bacteria to Plant Diseases. . . . . . . . . . ...... 66

Pathogenetists and Predispositionists. . . . . . . . . . 71

The Present Era $(1906$ - . . . . . . . . . . . . . . . . . . 108

Establishment of Chairs of Plant Pathology in Universities and

Colleges of Agriculture. . . . . . . . . . . . . . . . 109

Discovery of the Cause and Nature of Crown Gall . . . . . . . . 109

Establishment of the American Phytopathological Society . . . 110

The United States Quarantine Act of $1912 \ldots \ldots \ldots \ldots \ldots \ldots 11$

The Introduction of Sulfur as a Substitute for Copper in Fun-

gicides........................... 112

Development of Disease-resistant Crops. . . . . . . . . . . 113

The Epiphytotic of Chestnut Blight............... 114

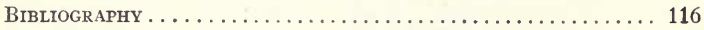

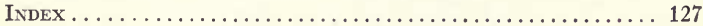





\section{AN OUTLINE \\ $\mathrm{OF}^{\circ} \mathrm{THE}$ \\ HISTORY OF PHYTOPATHOLOGY}

\section{INTRODUCTION}

THE science of phytopathology, like all natural sciences, had its beginning in the dawn of man's civilization. All wild plants have diseases, and from the time that man began to domesticate by cultivation those of the wild species that suited his needs, he must necessarily have observed and considered the diseases that robbed him of part or all of the fruits of his labor. Not until he acquired the art of writing, however, could he record his observations and opinions with respect to the maladies which affected his crops. Even long thereafter, records of plant diseases were but fragments woven here and there into his historic or religious writings. Later, as he began to seek for order in the multitudinous facts of nature, his observations on plant diseases were segregated more or less along with the related facts and data into his writings on botany and agriculture. Only in relatively modern times have there been attempts to organize the facts and phenomena of disease in plants into a separate science of plant pathology.

A history of the science of phytopathology has not yet been written. Such a history must be based on the ob- 
servations and interpretations of phytopathologic phenomena as found in the preserved writings of the race. There are, to be sure, a number of short papers or chapters in books dealing with the subject, but they are not at all comprehensive. One of the best is to be found in the first volume of Sorauer's Handbuch der Pflanzenkrankheiten (1909), a recent translation of which by Miss Dorrance (1914) makes it available to the English reader. Another interesting paper is that by Arthur (1906), which gives one a very good notion of the ideas of some of the earlier writers who undertook the organization of our science. Count Filippo Ré, in the introduction to his essay on diseases of plants (1807), gives an interesting list of phytopathologic writings prior to his day. A preliminary survey of the field has been made by Jensen (1909) in a thesis presented at Cornell University.

We can best approach the subject through a chronologic survey of the available data. This will insure a logical consideration of the landmarks in the evolution of the science and a sequential introduction of the men who have shaped its progress.

The history of phytopathology divides itself into eras, and these again into periods. Each era is characterized by a general and dominating point of view regarding the nature, cause, and control of diseases in plants; the beginning of each is marked by an epochal change in this point of view. These changes from one era to the next come as the result not only of accumulation and organization of phytopathologic facts and theories, but are profoundly affected, in fact often largely determined, by revolutionary discoveries in the fundamental sciences on which 
plant pathology is based. That these eras in our science are often almost coincident with great historic epochs is also significant. So sharp usually has been the change from one era to the next that we may wi h considerable accuracy designate the year, or decade at least, which marks the passing of one and the inauguration of another. I shall designate these eras as follows: (1) the Ancient Era; (2) the Dark or Middle Era; (3) the Pre-modern or Autogenetic Era; (4) the Modern or Pathogenetic Era, and (5) the Present Era.

Each era divides itself more or less sharply into periods - phases in the development and crystallization of the prevailing point of view of the epoch. Since the thought of each period, in the development of this, as of other sciences, has been strongly influenced, in fact often molded, by the life and works of some one man, I shall, as far as practicable, designate each period by a name indicating its dominating personality, following in general the nomenclature used by Jensen (1909). 


\section{THE ANCIENT ERA}

THIs may be said to begin with the earliest records of plant diseases (to be found chiefly in ancient religious writings, especially the Bible), and extending down to about the time of the fall of the Roman Empire in the fifth century (476 A. D.). It falls naturally into three periods: the Hebraic, the Theophrastian, and the Plinian.

\section{HEBRAIC PERIOD}

The Hebraic period includes the centuries covered by the Old Testament down to the rise and development of ancient Greece, about 500 B. C., when the Jews as a free people ceased to exist.

The data recorded by Hebrew writers consist largely of mention of blightings, blastings, rusts, mildews, and smuts of the crops of this ancient people. The cause of these maladies was laid to the Deity, of whose wrath or disfavor they were regarded as an expression. The general character of these records will be seen by consulting the following Biblical references: Genesis $41: 23$; 1 Kings $8: 37$; Deut. $28: 22$; Amos $4: 9$; Haggai $2: 16,17$; 2 Chron. $6: 28$.

\section{THEOPHRASTIAN PERIOD}

The Theophrastian or Greek period covers the time from the rise of the Greek peoples, about 500 B. C., to the end of the Macedonian supremacy about 320 B. C. The recorded observations on plants and plant diseases 
made by the Greeks during this period are to be found in the writings of their great philosophers, Aristotle and Theophrastus. According to E. L. Greene (1909:49) the first plant pathologist was a Greek, one Cleidemus, a rhizotimos whose observations on the diseases of the fig, the olive, and the vine are quoted by Aristotle.

Theophrastus of Eresus was the first great botanist of whom we have authentic records. He lived at about the same time as Aristotle (370-286 B.C.), whose pupil he was, and to whom the great philosopher, dying, bequeathed his library and botanical garden at Athens. Theophrastus is generally regarded as the Father of Botany. Chapter II in Greene's 'Landmarks in Botanical History" (1909) gives a very clear picture of the life and works of this greatest of all ancient botanists. His works abound with references to plant diseases. Some excerpts from his Historia Plantarum ${ }^{1}$ will indicate the breadth of his knowledge and the accuracy of his observations:

"As to diseases - they say that wild trees are not liable to diseases which destroy them. Cultivated kinds, however, are subject to various diseases, some of which are, one may say, common to all or to most, while others are special to particular kinds. General diseases are those of being worm-eaten, of being sun-scorched, and rot."

"The olive, in addition to having worms (which destroy the fig too by breeding in it), produces also a 'knot'

${ }^{1}$ Hort, Sir Arthur: Theophrastus' enquiry into plants; and minor works on odors and weather signs, with an English translation, $1: \mathrm{I}-$ XXVIII + 1-475; $2:$ I-IX + 1-499. 1916. (Greek and English text on opposite pages.) See especially $1: 391-413 ; 2: 201-209$. 
(which some call a fungus, others a bark blister), and it resembles the effect of sun-scorch. The fig is also liable to scab."

"The fig is also often a victim to rot and to krados." "Scab chiefly occurs when there is not much rain, after the rising of the Pleiad."

"Moreover, there are certain affections, due to season or situation, which are likely to destroy the plant, but which one would not call diseases; I mean such affections as freezing and what some call scorching."

"As to diseases of seeds - some are common to all, as rust, some are peculiar to certain kinds; thus chick-pea is alone subject to rot." "Some again are liable to canker and mildew, as cummin. But creatures which do not come from the plant itself but from without do not do so much harm."

"Generally speaking, cereals are more liable to rust than pulses, and among these barley is more liable to it than wheat; while of barleys, some are more liable than others, and most of all, it may be said, the kind called 'Achillean.' Moreover, the position and character of the land make no small difference in this respect; for lands which are exposed to the wind and elevated are not liable to rust, or less so, while those that lie low and are not exposed to wind are more so. And rust occurs chiefly at full moon."

Aristotle incidentally records the epiphytotic occurrence of rusts, but Theophrastus appears to have made a careful study of these diseases in cereals as they occurred in his day in ancient Greece. So frequent and destructive were these diseases that the ancient Greek farmer regularly besought Ápollo or some other of his numerous 
gods to shield his fields from the pestilence (Eriksson and Henning, $1896: 7-9)$. Thus did the Greek philosophers shrewdly speculate as to the cause of these diseases, while the husbandman dedicated such pests to special gods (Ward, 1901 : 86). (See also Sorauer, 1909 : 38, 39.)

\section{PLINIAN PERIOD}

The Plinian or Roman period extends from 320 B. C. to about the time of the fall of the Roman Empire in the fifth century ( $476 \mathrm{~A}$. D.). This period is named for the great Roman encyclopedist, Plinius Secundus, who lived from 23 to 79 A. D., and who brought together in his writings the knowledge of his day on natural history (E. L. Greene, 1909 : 155). The ancient Romans placed responsibility for diseases and injuries to their crops, along with their other misfortunes, on the gods or the stars. To quote Pliny, "The evil influence of the stars depends entirely upon the Heavens; on this account there must be included among the effects, hail as well as blight and the injury caused by white frost. The blight especially attacks tender plants, if, enticed by the warmth of spring, they venture to break through the ground, and it singes the juicy buds of germinating plants. In blossoms this is called blasting" (Sorauer Transl., $1914: 43)$.

There is abundant evidence in the writings of Pliny and other Roman authors of this period that plant diseases were not only common and destructive but also subjects of study by philosophers and of prayer by farmers. Pliny's observations on the relative severity of the rust on wheat and barley in ancient Rome were just the opposite from those of Theophrastus in Greece. He holds 
the wheat to be the more seriously affected. He also absolves the sun from all responsibility in bringing on the disease. He regards the rust as the most destructive of all cereal crop diseases. He recommends two methods of control: early sowing of the grain so that it will ripen before the rust comes on; and the sticking of laurel branches in the soil throughout the field, so that the rust may go over on these. Columella, another Roman writer, recommends that great piles of chaff be distributed about fields and vineyards and that these be fired when frost threatens, thus preventing frost injury and rust. So important a part did the rust play in Roman agriculture that a special rust-god pair, Rubigus and Rubigo, were evolved and an annual festival to propitiate them was instituted. A Roman legend explains the rust to be a curse sent on farmers as the result of the act of a wicked boy, who burned a fox which he caught robbing his father's hen roost (Eriksson and Henning, 1896 : 9-11).

Summary.-This ancient era comprises within itself a very distinct unit in human progress. Particularly is this true of all science and learning. For centuries to follow little or nothing was to be added to the sum of scientific knowledge; what had been gained by the observation and studies of the ancient philosophers was to be all but lost in the darkness of the Middle Ages. This is strikingly true of phytopathologic learning. A careful review of such records as are left to us from this era indicates that considerable advances in an understanding of the fundamental features of phytopathology had been made. (1) Of the nature of disease in plants little of our modern conception is to be discovered in the philosophies of this epoch. On the other hand, the observations on immunity 
and susceptibility and the explanations offered therefor fall not so far short of present-day progress in this direction. (2) The etiology of disease in plants was largely shrouded in mystery and supersitition. Of the causal relation of living organisms to disease in plants, the most advanced of these ancient thinkers appear to have had not the slightest suspicion. On the other hand, they seem to have had an accurate conception of the causal relation of such factors as drought, freezing, and winds. (3) Their conclusions and recommendation respecting control are odd mixtures of accurate reasoning and blind superstition, as witness the two methods suggested by Pliny for the control of the wheat rust and the smudging urged by Columella for protection of the vine against frost and of the grain against rust. 


\section{THE DARK ERA}

ThE Dark or Middle Era includes what is known in civil history as the dark ages, covering roughly the period from the fall of the Roman Empire (476 A. D.) until the beginning of the seventeenth century. The writings of this period show little that is new regarding plant diseases. This was the period when science and learning may be said to have slumbered, hence it is not strange that so fragmentary and unorganized a body of knowledge as was phytopathology at that time should have had few additions even in the form of isolated observations.

There is, however, one bright spot in the all but universal darkness. This is the work of the Arabian country gentleman and agricultural encyclopedist, Ibnal-Awam. He lived and wrote during the tenth century at Seville, Spain. Thoroughly familiar with the writings of Theophrastus, Pliny, and other ancient writers on agriculture, including those of ancient India, he was nevertheless an independent observer and thinker. His phytopathologic comments are almost entirely on the diseases of trees and the vine. He describes the symptoms of many diseases briefly but with accuracy and gives extensive consideration to their control (Savastano, $1890-91: 16,17,70){ }^{1}$

${ }^{1}$ Clement-Müllet, J. J.: Le livre de l'agriculture d'Ibn-al-Awam (Kitab-al-Felahah). Traduit de l'Arabe, $1: 1-100$ (Preface) + 1-657 + Index 1-24, 1864; $2: 1: 1-460,1866 ; 2: 2:$ I-X + 1-293, 1867. For his treatment of diseases of trees and other plants see vol. 1, ch. 14, pp. 543-597. Savastano $(1890-91: 16)$ in citing this translation 
The revival of interest in ancient Greek and Roman literature which began in the fourteenth century and became so general and enthusiastic throughout Europe in the fifteenth century, brought to the attention of the scientist and layman the observations and philosophies of Theophrastus and Pliny regarding the diseases of plants. But the statements of these philosophers were blindly accepted and no attempts were made to verify or disprove then by actual observation. The few writers on agriculture during the latter part of this dark era contented themselves for the most part with repeating merely the statements of the ancients (Sorauer Transl., $1914: 45)$.

gives volume 3 as the one in which data on diseases of plants is to be found. This appears to be an error, as I am unable to discover any "volume 3." Part 2 of the second volume, which might have been meant, deals with diseases of animals. 


\section{THE PREMODERN ERA}

THIs era may be said to begin with the seventeenth century and extend to about the middle of the nineteenth. It was ushered in by the first recorded observations on plant diseases and their control since the days of the ancient Greeks, Romans, and Arabians. An epoch during which observations and classification dominated natural science in all Tines, we find here for the first time attempts at the classification of the phenomena of plant diseases. During this era were written the first books on plant diseases. Since of all the applied sciences, human pathology was in this age the most powerful and respected, it is not surprising that the sister science, plant pathology, should have been largely influenced, in fact dominated thereby, particularly in its nomenclature and philosophy. Imbued with the dogma of spontaneous generation, the phytopathologic philosophers of this era brought to its perfection the theory of the autogenetic origin and nature of disease in plants.

This epoch may be divided into three periods: the Renaissance, the Zallingerian, and the Ungerian.

\section{THE RENAISSANCE PERIOD}

This period embraces, roughly speaking, the seventeenth century and may be said to have opened with the publication in 1600 of the Oeconomia and Haussbuch by 
Coler, ${ }^{1}$ in which is included information on diseases of plants. This work consists largely, hewever, of repetition of the statements of ancient writers. The evil influence of the stars is soberly set forth. Peter Lauremberg, ${ }^{2}$ in his Horticultura published in 1631, "relates that certain stars like Orion, the Pleiades, and others exert an especially injurious influence from which the so-called 'secret evils' arise, among which belong rust, carbuncle, and mildew" (Sorauer Transl., $1914: 45$ ). It is interesting that the practical growers, especially educated gardeners, had more to do with the revival of interest in the study of plant diseases than did the botanists or other scientists of this period. Observations on the symptoms of diseases and details of so-called practical methods of control appeared in books on gardening. The general character of the better writers on plant maladies during this time may be illustrated by the point of view of Heinrich Hesse ${ }^{3}$ in his Neue Gartenlust (1690)

$1 *$ Coler, Johannis: Oeconomia, oder Hausbuch. Ander Theil. Buch V, Kap. 12, 1600. This date is the one given by Sorauer, Handbuch d. Pflanzenkr. 1:41, 1909. I was unable to see the original. Haller, Bibliot. Bot. $1: 387$, gives but two editions of the "Ander Theil," 1595 and 1598. The work was issued in six parts and these were frequently reprinted, separately and together, throughout the 17 th century.

${ }^{2}$ Lauremberg, Petrus: Rostochiensis horticultura. Libris II. comprehensa; huic nostro coelo et folo accomodata; regulis, observationibus, experimentis et figuris novis instructa; in qua quicquid ad hortum proficue colendum et eleganter instruendum facit, explicatur, pp. 1-196. Francfurti, 1631. See especially caput XXXV, "De avertendis et corrigendis aeris iniuriis."

$3 *$ Hesse, Heinrich: Neue Gartenlust d. i. gründliche Vorstellung wie ein Lust-, Küchen-, und Baumgarten unter unsern Climate füglich anzurichten, u. s. w., pp. 1-416. $10 \mathrm{Kpf}$. Leipzig, 1690.

* References marked with an ${ }^{*}$ have not been seen by the author. 
in which he gives as the three chief causes of the blighting of trees: (1) superfluous sap with inflammation of the sap; (2) resetting a tree in a position different from that in which it originally stood (he preserved trees thus reversed by coating the south side of the body with a mixture of cow manure, oat chaff, glue, and ashes); (3) using a bread knife in grafting a tree. He subscribes to the ancient superstitions to a marked degree as is evidenced by his opinion that cankers on trees result from grafting the tree at the time when the moon lies in the sign of the crab or scorpion. He says, "This disease may be recognized by the fact that here and there the bark throws up little hummocks under which the tissue is dead and black. This spreads further and further, ultimately infecting the whole trunk. Many scattered causes of canker have been brought forward, but the one given above is the most probable of all" (Sorauer Transl., $1914: 45,46)$.

Reference to the common and destructive occurrence of rusts and smuts in cereal crops again appears in writings on agriculture. Especially in England where these diseases were known under the names of blight and mildew they were reported as very destructive during this period. It is interesting that the first law, so far as records show, directed toward the control of a plant disease, was enacted during this period. It was in Rouen in France in 1660 that a decree was promulgated directing the grubbing out and destruction of all barberry plants, as they were held to bear some mysterious relation to epiphytotics of wheat rust (Eriksson and Henning, $1896: 12$ ).

Summary. - The Renaissance period of the pre-modern 
era is characterized: (1) by the revival of general interest in plant diseases as is seen from the numerous records in the agricultural literature of the 17th century; (2) by the evidence that this interest was especially pronounced among the educated agriculturists and gardeners; (3) by the fact that with respect to the cause of these diseases opinion was largely dominated by the philosophies of the ancients and by superstition; (4) by the attempts to develop practical methods of controlling diseases in plants, and (5) by the enactment of the first law directed toward plant disease control.

\section{THE ZALLINGERIAN PERIOD}

The Zallingerian or taxonomic period covers the 18th century. It is characterized by attempts to name and classify the diseases of plants much after the fashion of naming and classifying plants themselves. The names of the various plant diseases are copied from or fashioned after those employed in human medicine for supposedly similar diseases, and the classifications employed are largely adaptations from those used in classifying the diseases of man and animals. The period was ushered in during the time of the revival of interest in systematic botany, which culminated in the publication of Linnæus' system of nomenclature (in Species Plantarum) in 1753. Naming and classifying was the order of the day and this early period of modern plant pathology was largely dominated by the taxonomic mode of thinking which prevailed among the scientific men of that time.

Phytopathologic thought and writings during the early part of this period were, however, to be influenced not 
only by the taxonomic philosophers and medical men but also by the practical gardeners, evidences of whose influence we have already noted in the writings of the previous period. We thus discover during the premodern era two points of view in plant pathology, the philosophic and the practical, clearly marked, at least as far as the writers on the subject are concerned. Not until the middle of the nineteenth century are we to see these two points of view united by Julius Kühn, the first real plant pathologist who effectively applied the scientific knowledge of his day to the practical solution of plant disease problems.

This period may be said to begin with the presentation in 1705 of a paper by that noted French botanist Joseph Pitton de Tournefort, under the title: Observations on the maladies of plants. ${ }^{1}$ It is worthy of note that Tournefort's classification was the first to present the division of all plant diseases into two great groups, viz., (a) those due to external causes, and (b) those due to internal causes, a division very similar to that employed by some pathologists of more modern times. Tournefort's work on plant pathology has had little recognition, as his fame rests on his work as a taxonomic botanist.

Following Tournefort's treatise appeared a number of works on plant diseases, all more or less systematic in character. Among these may be mentioned the following:

Christian Sigismund Eysfarth, ${ }^{2}$ a German, presented

${ }^{1}$ Tournefort, J. P. de: Observations sur les maladies des plantes, Mem. Mat. et Phys. tirez des registres Acad. Roy. Sci. de l'anne 1705: 332-345, Paris, 1730.

2 * Eysfarth, Christian Sigismund: Dissertationem physicam de morbis plantarum, pp. 1-48, Lipsiae, 1723. 
as a thesis for his doctorate at Leipzig, in 1723, a dissertation on the physiology of the death of plants, in which he classifies diseases according to the period of the plant's life in which they appear, thus, (1) diseases of the germinating period, (2) diseases of the vegetative period, and (3) diseases of the fruiting period (Sorauer, $1909: 45)$.

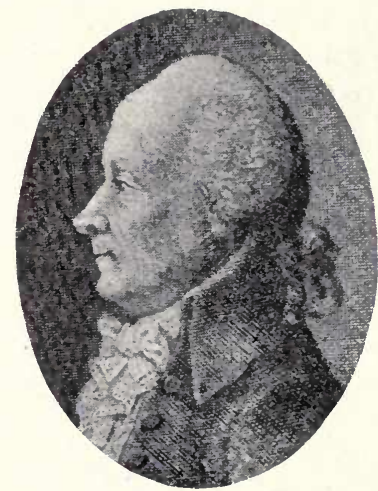

Johann Christian Fabricius.

The first pathogenetist. (After an engraving in Lind's "Danish Fungi.")

Johann Christian Fabricius, the first Dane to write on plant pathology, published his complete classification in 1774 in his Essay on phytopathology, ${ }^{1}$ in which he presents views far in advance of his day. He holds, for

${ }^{1}$ Fabricius, Joh. Christ.: Forsög til en Afhandling om Planternes Sygdomme. In Det Kongl. Norske. Vidensk. Selsk. Skriften, 5 : $431-$ 492, Kiobenhavn, 1774. What appears to be this same thing is cited by Boehmer in his Handbuch der Naturgeschichte, $3: 1: 523$, thus: "Joh. Chr. Fabricius de morbis plantarum; in Act. Soc. Scient. Norweg. To. 5. p. 431." No date is given. 
example, that fungi found associated with disease lesions are distinct organisms and not morbid plant tissues, a view which was not to be generally accepted until more than seventy-five years later. He was primarily an entomologist and his phytopathologic writings had little influence on contemporary phytopathologic thought. His name is nevertheless not to be forgotten, for he stands forth as one of those geniuses whose misfortune it was to have lived and thought long before the world was able to understand them (Lind, $1913: 19,20$ ).

Michel Adanson, another noted French botanist of this period, also contributed a chapter to the maladies of plants in his work on Familles des Plantes. ${ }^{1}$ He follows Tournefort and Fabricius in classification and terminology (Sorauer, 1909 : 46).

The most striking phytopathologic publication of this period is that by Johann Baptista Zallinger, De morbis plantarum, a German translation of which appeared in 1779.2 In this work the attempt to utilize the terminology of animal pathology reached its climax. Zallinger made five general classes of plant diseases, viz.: (1) Phlegmasiæ, or inflammatory diseases, (2) paralysis or debility, (3) discharges or draining, (4) cachexia, or bad constitution, and (5) chief defects of different organs. Zallinger strongly upheld the idea that fungi found associated

${ }^{1}$ Adanson, Michel: Maladies des plantes. In Familles des plantes, $1: 42-53,1763$.

${ }^{2}$ Zallinger, J. B.: De morbis plantarum cognoscendis et curandis dissertatio exphaenomensis deducta. (Diss.), pp. 1-137 + apx. Oemponti, 1773. Translated into German by Johann Grafen von Auersberg under the title Abhandlung über die Krankheiten der Pflanzen, ihrer Kenntniss und Heilung; aus dem Lateinischen ubersetzt, pp. 1-6 + 1-143, Augsburg, 1779. According to Berkeley (Gard. Chron., 1854 : 20) a German translation of this appeared as late as 1809. 
with disease in plants are but abnormal structures of the plants themselves resulting from, rather than the cause of, the diseased condition, and this theory with respect to one of the most fundamental facts of modern pathology was to dominate the thought of the following period (Sorauer Transl., 1914: 50).

The prevailing ideas regarding the etiology of diseases in plants were still largely those of the ancients. Belief in the rôle of the supernatural in the production of disease was, of course, less marked than in the preceding period, but it was still generally entertained. The causal nature of such environmental factors as drought, drying winds, hail, freezing, unfavorable soil, and the like was especially put forth and emphasized. The idea of the autogenetic origin of disease within the plant itself which was to prevail during the succeeding period was taking form in the minds of the contemporaries of Zallinger, as witness the statement of Ritter von Ehrenfels that "even at times the tendency to blight lies in the disposition of the tree itselfa disposition which the trees obtain from the soil in which they grow, from their descent, and from an unwise cultivation" (Sorauer Transl., $1914: 52$ ).

The practical gardeners and horticulturists were accumulating facts and observations on the diseases of plants with which they worked and were endeavoring to explain them in the light of the ancient theories and superstitions with regard to such phenomena, rather than in that of the scientific thought of their day. They were nevertheless beginning to devise treatments for these diseases and to test them through crude experiments. Their observations, theories, and remedies they set down in their books and articles on practical garden- 
ing and horticulture. The "practical" writings of this period differed strikingly from those preceding in the greater emphasis placed upon the treatment. Some of these recommendations sound very modern. For example, Riedel, ${ }^{1}$ in his Garten Lexicon, 1751 , gives as a remedy for canker, cutting out the diseased places and coating with grafting wax. On the other hand, his suggestion that trees be bled by boring a hole or splitting a root to relieve them of superfluous sap sounds ridiculous (Sorauer, $1909: 43$ ).

An English gardener, Stephen Hales, 1731, refers to the transmission of canker diseases in budding as evidence of the circulation of sap (Sorauer, $1909: 44$ ). Hales also offers an interesting explanation of the cause of hop mildew and records an epiphytotic of this malady in $1731 .{ }^{2}$

These studies of the practical horticulturists reached their climax in the discovery by William Forsyth in 1791 of a so-called "composition" or tree cement for the treatment of lesions on trees. ${ }^{3}$ This was widely ad-

$1 *$ Riedel, J. Christ.: Kurz abgefasstes Gartenlexikon nebst einem Garten-Calender, pp. 1-420, Nordhausen, 1751.

${ }^{2}$ Hales, Stephen: Statical essays; containing vegetable staticks; or an account of some statical experiments on the sap in vegetables, being an essay toward a natural history of vegetation; of use to those who are curious in the culture and improvement of gardening, etc., $1:$ I-XII + 1-376, London, 1731. (Canker transmission, p. 147; hop mildew, p. 33.) The earliest edition of this appears to have been that of 1727 . There were later editions, including a fourth, issued in two volumes in 1769.

${ }^{3}$ Forsyth, William: Observations on the diseases, defects, and injuries in all kinds of fruit and forest trees; with an account of a peculiar method of cure, pp. 1-71, London, 1791. This was translated twice into German, twice into French, once into Italian, and once into Danish. "A new and improved edition" of the above is to be found in the fourth edition of "A treatise on the Culture and Management of Fruit Trees," London, 1806, by the same author, pp. 407-484. 
vertised and, of course, overestimated, but had the effect of calling more general attention to the economic importance of plant diseases and created a demand for semi-technical works on the subject. Such were immediately forthcoming. Three books of this type appeared in the years 1794 and 1795 alone.

Perhaps the most important of these is that by Plenck, on the physiology and pathology of plants. ${ }^{1}$ The author attempts to treat the diseases of all cultivated plants of importance at that time. This work is valuable because based apparently on thorough observation. The two others are: Schreger's Introduction to a correct understanding of the diseases of trees ${ }^{2}$; and Ritter von Ehrenfels' Diseases and injuries of fruit and garden trees. ${ }^{3}$ Both give good descriptions of cankers, especially of the Nectria canker still so destructive in Europe. They attribute most of the ailments of plants to unfavorable soil conditions, climate, or the inherent disposition of the plant to become diseased (Sorauer, 1909 : 48). Writings dominated by the theories and dogmas of this period continued to appear far into the nineteenth century and were numerous during the early

${ }^{1}$ Plenck, Joseph Jacob von: Physiologia et pathologia plantarum, pp. 1-192, Veinnae, 1794. (Pages 123-184 only, deal with pathology including insect injuries.) This was translated into Italian by $\mathrm{G}$. Pagani in 1804 under the title: Fisiologia e patologia delle piante.

$2 *$ Schreger, B. N. G.: Erfahrungsmassige Anweisung zur richtigen Kenntniss der Krankheiten der Wald- und Gartenbäume, der Getreidearten, Futterkräuter, Küchengewächse und Blumen, nebst den bewährtesten Mitteln dagegen; für Forstbediente, Oekonomen und Gartenliebhaber, pp. 1-518, Leipzig, 1795.

${ }^{3 *}$ Ehrenfels (J. M.), Ritter von: Über die Krankheiten und Verletzungen der Frucht und Gartenbäume, pp. I-XX + 1-232, Breslau, 1795. 
years of the Ungerian period, which is next to be considered. They were of little influence, however, and to be considered only as echoes of a point of view already on its way to the limbo of scientific rejecta. Sorauer (1909:49) refers to one such published in $1818 .{ }^{1}$

The publication in 1807 by Freiherr von Werneck of his Investigations in plant pathology and therapy, ${ }^{2}$ and the Essay, theoretical and practical, on diseases of plants, ${ }^{3}$ by the Italian Filippo Ré, mark the close of this period. Both were philosophical rather than practical, following much the same lines as those of their contemporaries.

The characteristic features of the Zallingerian period may be summarized as follows: (1) Phytopathologic thought and writings were distinctly taxonomic; (2) the basis of classification was symptomologic; (3) modern practices in plant disease control had their beginnings in this period; (4) the cause of disease in plants was generally attributed to occult influences or to the effects of the elements, especially unfavorable soil, winds, low temperatures, and the like, but the theory of the autogenetic nature of disease was beginning to take form.

1 * Burdach, Heinrich: Systematisches Handbuch der Obstbaumkrankheiten, Berlin, 1818.

2* Werneck (L. F. F.), Freiherr von: Versuch einer Pflanzen Pathologie und Therapie; ein Beitrag zur höhern Forstwissenschaft, pp. 1-60, Mannheim, 1807.

${ }^{3}$ Ré, Filippo: Saggio teorico pratico sulle malattie delle piante, pp. 1-437, Venice, 1807. A second edition appeared in 1817 from Milan, pp. 1-331. An English translation of this appeared in Gard. Chron., 1849, p. 211, and running throughout the numbers for nearly two years. An earlier work of the same sort, under the title: * Saggio di nosologia vegetabile, Mem. di Mat. e di Fisica Soc. Ital. delle Scii., 12 : 2 : 225-255, appeared in 1805 . 
This period saw the early attempts of scientists to assemble and organize the scattered and apparently unrelated facts and phenomena of disease in plants. The writings of the period constitute the record of the real beginnings of the science. From these pioneer attempts was to develop with astounding rapidity the phytopathology of the present, which is even yet to some degree in the process of delimitation and crystallization. In the periods to follow we shall see something of the lines along which and of the great minds by which this development has been effected.

\section{THE UNGERIAN PERIOD}

The Ungerian period extended from about 1807 to 1853. This period might well be designated the physiologic or autogenetic period, since the theories and investigations on plant nutrition, sexuality, and irritability largely dominated botanical thought, eclipsing to a marked extent the taxonomic point of view of the preceding period. This is strikingly brought out by the fact that the most important works on plant pathology were written by men primarily plant physiologists, and those too among the greatest of their day. It is also worth noting in passing that they were all doctors of medicine and practised their profession at the beginning of their careers. During the early part of the period no contributions of marked worth appeared. The men who were to express the ideas and shape the evolution of our science during this time were getting the training and experience which was finally to appear in the distinctive contributions of their day.

Among the botanists whose work strongly influenced 
the writers on plant pathology of this period were the elder De Candolle, the noted French savant, and the German writers, Schleiden and Sprengel. Sachs, in his History of Botany, characterizes this period (1800-60) as the one in which "botanical science developed from one founded on misinterpreted observation and natural philosophy to a real science founded on investigation and research." While this characterization could scarcely apply to the plant pathology of this period, it certainly does to that of the following period. Nevertheless this revolution in botanical thought influenced powerfully and made possible a similar revolution in phytopathologic thought during the last half of the 19 th century.

The first and most characteristic work of the Ungerian period is that by Franz Unger, after whom the period is named. Franz Joseph Andreas Nicholas Unger ${ }^{1}$ was born at Leutschach, South Germany, in 1800, and died in 1870. He took his degree of doctor of philosophy in law at the age of twenty; studied and practised medicine for the next fifteen years at Vienna and in the Tyrol. While stationed as army surgeon at the latter place he gave much of his time to botany and plant pathology, publishing as a result of his studies among other things the work referred to above. It was here that he maintained a plant disease garden, probably the first of its kind. He devoted the remainder of his life to the teaching of botany, being for fifteen years professor of vegetable physiology at the University of Vienna, from where he wrote several books on plant physiology.

${ }^{1}$ Wittrock, in Acta Horti Bergiani, $3: 3: 86$ and table 56, gives his name as Franz Xaver Unger. 
In his book, Exantheme der Pflanzen, ${ }^{1}$ published in 1833, Unger devotes 20 pages to the relation of fungi to the plants on which they live. He calls them entophytes or "disease organisms," not parasites, ${ }^{2}$ holding firmly to the idea of the previous period that they originate from the diseased host tissues, but at the same time he

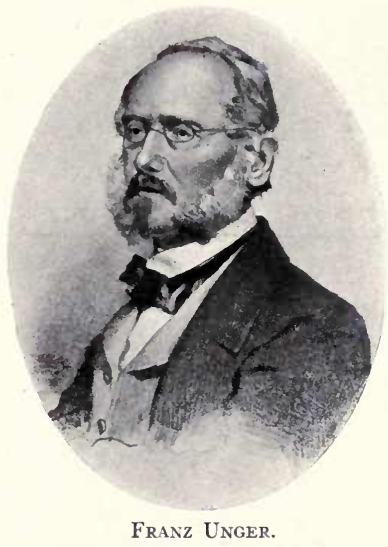

The greatest autogenetist. (After a portrait in Wittrock's "Acta Horti Bergiani.")

recognizes them as distinct organisms, worthy of names and classification.

${ }^{1}$ Unger, Franz: Die Exantheme der Pflanzen und einige mit diesen verwandete Krankheiten der Gewächse, pathologisch und nosographisch dargestellt, pp. 1-421, Wien, 1833.

${ }^{2}$ Unger, Franz: Originäre Bildung der Krankheitsorganismen. In Beitrage z. Vergleichenden Pathologie. Sendschreiben an Herrn Professor Schönlein, pp. 39, 40, Wien, 1840. 
He believes diseases to be conditions brought about through internal disorganization of the nutrition processes; that they have their origin in a lack of certain chemical constituents of the sáp. He observed, however, that "entophytes," the fungi, protrude their structures from the stomates of the diseased plant (see his sketches) and concludes that they must be the transformed sap of diseased tissues. His theory is that this morbid sap exuded into the substomatal cavities and intercellular spaces is converted, under the influence of the still living cells of the host, into fungous structures, $i$. e., conidiophores and spores. Of mycelium he seems to have had no true conception, as may readily be gathered from his drawings of cross-sections of diseased leaves. The theory of spontaneous generation, generally accepted by the scientific men of his time, was also for Unger a fundamental conception, hence his idea of the relation of pathogene to host was but a natural and logical deduction. Nevertheless, mycologists of the period were collecting and studying fungi, observing the character of their spores and their manner of germination. Some were even contending that the entophytic forms were entirely distinct from their host plants. Their observations and deductions were not to materially influence during the Ungerian period the generally accepted explanation of the relation of the fungus to the plant on which it grew. Their work and their ideas were, however, to profoundly affect the phytopathologic thought of the next period, as we shall see.

Unger dominated the phytopathologic thought of his time, as is strikingly shown in the work of Arend Joachim Friedrich Wiegmann, whose book on "The diseases and 
disease abnormalities of plants" ${ }_{1}$ appeared in 1839 . Wiegmann accepts Unger's explanation of the nature of disease in plants and the relation of the fungi found associated with the lesions. He cites Unger's book extensively, setting forth in much simpler language, however, the autogenetic doctrine of disease in plants. Wiegmann's book differs distinctly from that of Unger in that it purports to be a handbook for farmers and gardeners rather than a scientific treatise. He covers much the same ground as Unger, but adds a discussion of means of control, a phase of the subject not considered by Unger. Wiegmann claims to have thoroughly tried out the various remedies he recommends.

Next to Unger, the most dominating personality in the phytopathologic thought of the Ungerian period was Meyen, a remarkable young botanist who at his death was professor of botany at the Imperial University at Berlin.

Franz Julius Ferdinand Meyen was born at Tilsit in Posen in 1804. He was the son of a bookkeeper in a small store. Leaving the gymnasium early, he began to study pharmacy, but eventually studied medicine, taking his degree in 1826. He practised four years and then went for a botanizing trip around the world. Returning, he was made professor of botany at Berlin, where he remained until his death at the age of thirtysix. Meyen was one of the most brilliant and productive botanists of this period. His writings cover the whole

${ }^{1}$ Wiegmann, A. F. sen.: Die Krankheiten und krankhaften Missbildungen der Gewächse. Ein Handbuch für Landwirthe, Gärtner, Gartenliebhaber und Forstmänner, pp. I-XII + 1-176, Braunschweig, 1839. 
field of botany, but more especially plant physiology (Ratzenburg, 1843).

Meyen's book on Plant Pathology ${ }^{1}$ which appeared the year following his death is, next to Unger's Exantheme der Pflanzen, the most important contribution of this period. This work was intended to constitute the final contribution to a series of works by the author

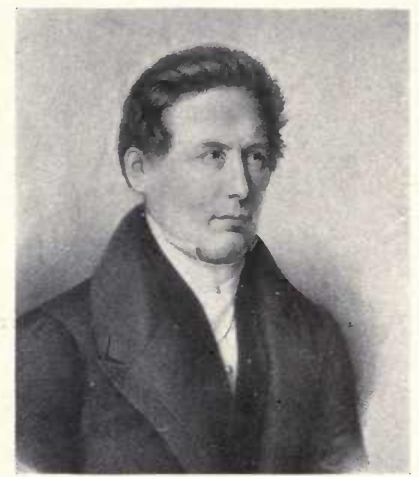

Franz Julius Meyen.

(From an engraving in the Kaathoven collection. Courtesy of the Library of the U. S. Surgeon General's Office.)

on ${ }^{\overline{2}}$ botany, of which his three-volume work on Neuen System der Pflanzen-Physiologie is the most remarkable and important. It was to consist of two volumes, the second to be on teratology, and was to appear under the general title of Handbuch der Pflanzen-Pathologie und

${ }^{1}$ Meyen, F. J. F.: Pflanzen-Pathologie. Lehre von dem kranken Leben und Bilden der Pflanzen, pp. I-XII + 1-330, Berlin, 1841. 
Pflanzen-Teratologie. The manuscript for the first volume was largely completed before his death and was published a year later by his friend, Nees von Esenbeck (see Vorerinnerung in same, V-VIII).

Meyen's Pflanzen Pathologie is really only a careful classification and description of a large number of diseases. There is wanting in the book those general or introductory chapters in which authors are wont to set forth their generalizations and philosophies. We do not have, therefore, a summarized or organized statement of his ideas with respect to the nature of disease, the relation of the fungi found associated with disease lesions, and other fundamental pathologic theories so extensively set forth by Unger and even by Wiegmann. His early death is doubtless responsible for these omissions. The book gives one the impression of incompleteness. From his description of the smuts, the rusts, and the mildews it is, however, readily seen that his philosophy of disease in plants is not materially different from that of his phytopathologic contemporaries. His philosophy of disease, the nature of parasitic fungi, and their relation to their host plants is clearly indicated in a short paper on the development of smut in the maize plant. ${ }^{1} \mathrm{He}$ says it is an established fact that the cereal smut is not an infectious disease, but is one due to a stagnation of sap brought about by excessive and unnatural fertilizing. $\mathrm{He}$ describes and figures the formation of the spores as taking place within the host cells, and calls them pseudoorganisms, the product of abnormal nutrition. His

${ }^{1}$ Meyen, F. J. F.: Beiträge zur Pflanzenphysiologie. I. Über die Entwickelung des Getreidebrandes in der Mays Pflanze, Archiv. f. Naturgesch., 1 : 417-421, 1837. 
book shows in its detailing of facts and observations the marked influence of the mycologic discoveries of his age. Brilliant man though he was, he failed to understand their true significance and sought to explain them with the philosophy of Zallinger and his school of the 18th century.

Summarizing the characteristic features of the Ungerian period, we see that:(1) phytopathologic thought was distinctly physiologic, with a marked tendency toward the mycologic near the end of the period; (2) the basis of classification of plant diseases was etiologic, that, too, in spite of the fact that pathologists would not admit the causal relation of the associated fungi; (3) the influence of the practical gardener on the phytopathologic writings of the period was overshadowed by the researches and activity of scientists; (4) the influence of human medicine was still strongly marked; (5) the cause of disease in plants was held to be autogenetic. Increasing observations of the very general association of fungi with disease lesions was constantly raising the question whether these must not be the cause rather than the result of the diseased condition.

This was the transition period from old, long held, and firmly rooted beliefs and theories with respect to plant diseases to the modern ideas and point of view. 


\section{THE MODERN ERA}

THE doctrine of the autogenetic origin of disease in plants reached its high-water mark in the philosophy of Franz Unger, as we have already seen. The end of the eighteenth and the early days of the nineteenth century saw a growing school of mycologists whose observations and studies convinced them that the spore-like structures of the entophytic fungi were, in reality, reproductive bodies; that they germinate and hence must serve to propagate their kind; and finally that these entophytes must be independent organisms causing the diseased conditions with which they are constantly found associated and not the result thereof. To this school belonged such noted mycologists as Bulliard, DeCandolle, Link, Tulasne, Léveillé, and others (de Bary, 1853:107). Positive proof in the form of carefully checked infection experiments were, however, largely wanting

The brilliant and classic studies of the Tulasne ${ }^{1}$ brothers on the life history of such parasitic fungi as Claviceps, the Erysiphaceæ, the Uredinales, and the Ustilaginales had unfolded the fact of polymorphism in

${ }^{1}$ Tulasne, L. R. et Ch.: Mémoire sur les Ustilagineés comparées aux Urédinées, Ann. Sci. Nat., $3: 7: 12-127,1847$; and the following by L. R. Tulasne alone: Mémoire sur l'Ergot des Glumacées, Ann. Sci. Nat., $3: 20: 5-56,1853$; Second Mémoire sur les Urédinées et les Ustilaginées, Ann. Sci. Nat., $4: 2$ :75-196, 1854; and finally that extraordinary work by the Tulasne brothers, Selecta fungorum carpologia, ea documenta et icones potissimum exhibens quae viria fructuum et seminum genera in eodem fungo simul aut vicissim adesse demonstrent, 1: I-XXVIII + 1-242, 1861; 2 : I-XIX + 1-319, 1863. 
these forms. Zoölogic investigations ${ }^{1}$ had established the facts of heteromorphism among insects, notably in the case of aphids. The true relation of gall wasps, tapeworms, and other parasitic animals to their hosts was becoming increasingly clear to scientific workers.

Nevertheless, the deep-rooted theory of spontaneous generation still dominated to a great extent the doctrines on reproduction. Accumulating evidence against it and a growing understanding of the significance of this evidence were of themselves powerless to overcome the handicap which centuries of established acceptation gave to the prevailing dogma. The overthrow of this ancient superstition awaited the magic power of master minds. The middle of the nineteenth century saw their entrance upon the scientific stage. The brilliant researches and convincing demonstrations of that noted French savant, Louis Pasteur, ${ }^{2}$ swept away the nebulous foundations of spontaneous generation. Küchen-

${ }^{1}$ For classic works on this subject see-

Steenstrup, Johann Japetus Smith: Om Fortplantning og Udvikling gjennem vexlende Generationsvrikker en saeregen Form for Opfostringen i de lavere Dyrklassen, pp. I-IV + 1-76, Kjöbenhavn, 1842. A German translation by Lorenzen appeared in 1842 and from this an English translation by Rusk in 1845 under the title: On the alternation of generation; or the propagation and development of animals through alternate generations.

Owen, Richard: On parthenogenesis or the successive production of procreating individuals from a single ovum, pp. 1-76, London, 1849.

Siebold, Carl Theodor Ernst von: On a true parthenogenesis in moths and bees; a contribution to the history of reproduction in animals. Translated from the German by William L. Lallas, pp. I-VIII + 1-110, 1857. The original appeared in 1856 .

${ }^{2}$ Frankland, P., and Frankland, Mrs. P.: Pasteur, pp. 1-224, New York, 1898. See especially ch. 5, and Vallery-Radot's, The Life of Pasteur, in two volumes, 1902, vol. 1, ch. 5 . 
meister' ${ }^{1}$ work on the animal parasites of man revolutionized the theories on animal parasitism. Darwin's painstaking researches into the origin of species $^{2}$ freed the biologic sciences of the deadening dogmas of special creation and fixity of forms. The wonderfully exact and extensive studies of that master mycologist, Anton de Bary, so completely established the independent nature of entophytic fungi that the theory of their metamorphosis from the sap of diseased plants was no longer tenable.

The wide-spread and destructive epiphytotics of the Phytophthora blight which swept the potato fields of Europe in 1844 and $1845,{ }^{3}$ resulting in famine in some sections, suddenly impressed everyone, layman and scientist, with the importance of plant diseases in the economic welfare of mankind. The most noted scientists of the time turned their attention to the solution of the problem thus presented. Learned societies and even governments appointed commissions to investigate the cause of the disease. This intensive investigation led naturally to a more general and critical examination of

${ }^{1}$ Küchenmeister, Friedrich: Die in und an dem Körper des lebenden Menschen vorkommemden Parasiten. Ein Lehr- und Handbuch der Diagnose und Behandlung der thierischen und pflanzlichen Parasiten des Menschen, Abt. 1:I-XVI + 1-486; Abt. 2:I-X + 1-148, Leipzig, 1855. An English translation appeared in 1857 under the title: On animal and vegetable parasites of the human body. A manual of their natural history, diagnosis and treatment, $1: \mathrm{I}-\mathrm{XIX}+1-443 ; 2: \mathrm{I}-\mathrm{XVI}$ $+1-287$.

${ }^{2}$ Darwin, Charles: On the origin of species by means of natural selection, or the preservation of favored races in the struggle for life, pp. I-IX $+1-502,1859$.

${ }^{3}$ Jones, L. R.: Investigations of the potato fungus Phytophthora infestans, U. S. Dept. Agr. Bu. Pl. Ind. Bul., 245 : 19-24, 1912. 
other diseases equally common though less strikingly destructive. This was especially true of the rusts and smuts of cereals.

Thus the middle of the nineteenth century saw the beginning of a new era in the science of phytopathology. In the establishment of the pathogenic nature of fungi, the autogenetic theory of disease in plants received a staggering blow. The day of the autogenetists had passed, and for the next half-century or more a new school, the pathogenetists, and the etiologic phases of phytopathology were to dominate the science.

The era falls naturally into two periods of approximately a quarter century each, the Kühnian and the Millardetian. The first of these is characterized by an almost complete devotion to the study of the causal relations of fungi to the diseases with which they are found associated; the second period saw a marvelous development and general application of methods of disease control. Together they constitute an era unparalleled in the history of plant pathology.

\section{THE KÜHNIAN PERIOD}

This period (1853-83) will always stand out as one of the greatest in the history of plant pathology. It is characterized chiefly by the discoveries which have firmly established the causal nature of fungi associated with plant diseases. As fungi are now generally recognized to be responsible for most of our plant diseases, the importance of the pioneer work of this period cannot be overestimated.

The phytopathologists of this period were powerfully influenced in their thought and theories by the works of 
three great scientists. None of them were plant pathologists, though all made investigations and discoveries not only epoch making in their respective fields, but fundamental to related sciences and to none more than phytopathology. I refer to the great German botanist and mycologist, Anton de Bary, who lived and worked from 1831 to 1888 ; the equally noted chemist, Justus Freiherr von Liebig, 1803-73, the father of agricultural chemistry; and the famous French chemist and bacteriologist, Louis Pasteur, 1822-95.

The opening of this period is marked by the publication in 1853 of that classical work of de Bary's, Die Brand Pilze, in which the young investigator (then twenty-two years old) established beyond doubt the causal nature of the fungi found associated with rust and smut diseases. In $1861^{1}$ he published his investigation on the cause and nature of the late blight of potatoes in which he proved the causal relation of Phytophthora infestans. In $1865^{2}$ he published his work, establishing the relation of the æcidium on barberry to the rust fungus on wheat. These are but a few of the striking pieces of work of an almost endless number of similar investigations on the nature of the relation of fungi to different diseases. One should read the list of his contributions in the Lindau and Sydow Thesaurus, Vol. I.

Heinrich Anton de Bary was born at Frankfurt-amMain. . He became interested in botany while still in the

${ }^{1}$ de Bary, A.: Die gegenwärtig herrschende Kartoffelkrankheit, ihre Ursache and ihre Verhütung, pp. 1-75, Leipzig, 1861.

${ }^{2}$ de Bary, A.: Neue Untersuchungen über die Uredineen, insbesondere die Entwickelung der Puccinia graminis und den Zusammenhang derselben mit Aecidium Berberidis, Monatsber. d. Kön. Preuss. Akad. der Wiss. aus dem Jahre 1865 : 15-50, Berlin, 1866. 
gymnasium, but fitted himself for the practice of medicine, taking his degree in 1853 , the same year in which he published the investigations on smut fungi, which, as we have already seen, marks the opening of this period. He practised medicine for two years in his native city, but abandoned it for research in botany. He began as in-

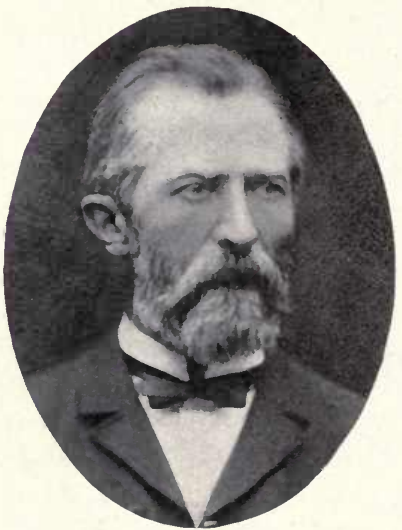

ANTON DE BARY.

Founder of modern mycology. His studies on the parasitism of fungi gave rise to the school of pathogenetists. (From a photograph, courtesy of Dr. Erwin F. Smith.)

structor in the University of Tübingen, becoming two years later professor at Freiburg until 1867. He then went to Halle, and finally in 1872 to Strassburg, where he remained until his death in 1888 . No less than sixtyeight men afterward noted for work in science studied under him in his laboratories in Strassburg. 
De Bary has been regarded by some as the father of modern plant pathology. Though there can be no doubt of the molding and dominating influence of his work on the plant pathology not only of this but of the succeeding period, still he was a botanist, a mycologist. He did not assume to be a plant pathologist. He did not concern himself extensively with the pathology of the diseases with which he worked, except from the point of view of the physiologist undertaking to discover the nature of the life of the parasite, its mode of attack, its method of feeding, and its life history. With the many other aspects of the disease, especially the economic, he concerned himself little. He wrote no books on plant pathology. To Julius Kühn, a countryman of de Bary, belongs, in my opinion, the title of Father of Modern Plant Pathology.

Julius Gotthelf Kühn was born in Pulsnitz, in Saxony, not far from Dresden, in 1825. His father was a land owner and it was the son's ambition to become an expert agriculturist. He received his elementary and gymnasium education, as well as some technical training, very largely in the schools of Dresden. In 1841 he returned to his father's estate to take up practical training as a "Landwirt." Six months later he became assistant to the manager of a large estate in Saxony. Here he spent two and a half years. The manager was a hard and exacting master but an excellent teacher, and Kühn did so well that in 1844, after three months as assistant manager on the estate of Graf Kospoth in Halbau, he was made administrator. For the next four years he was manager of different large estates; finally at the age of twenty-three (1848) he took charge as Amtmann (farmer 
of a crown domain) of the large estate of Gross-Krausche by Bunzlau in Silesia, remaining eight years. Here he began in earnest his agricultural investigations. Influenced by the writings of Liebig, he tested out the value of commerical fertilizers on a large scale. He tried out and introduced the drilling of grain and made extensive use of tile drainage. Through his activities along these lines he became known to his colleagues as the microscope farmer.

For us, however, his work on the diseases of his crops on this estate is of most interest. Here he not only gathered his fundamental training along these lines, but laid by extensive and exact experiments the foundation for his book on plant diseases to appear a few years later. His interest in plant diseases appears to have begun with some studies on Sporodesmium exitosum, the cause of a serious disease of rape. He studied and named the pathogene. His work attracted the attention of such men as Ferdinand Cohn, Göppert, and Rabenhorst. These years of practical study and experiment aroused in Kühn the desire for further training at some agricultural academy or some university.

The Agricultural Academy at Poppelsdorf loosely associated with the University of Bonn was at that time the most noted in Germany. Thither the young Amtmann turned his steps at the age of thirty in the autumn of 1855. Unfortunately, the teachers at Poppelsdorf had little new to offer this well-read and experienced farm manager, but in the University he had the chance to complete and round out his scientific training in the two semesters that he spent there. It was here at Bonn also that he conceived the idea that agricultural educa- 




JuLIUS KüHN.

Father of modern phytopathology. (After a portrait in the Deutsche Landwirtschaftliche Presse, vol. xxii.) 

tion could be best conducted as a department or faculty of a university rather than in a separate institution. This idea he himself was to be the first to work out in a most practical manner a little later in the University of Halle.

In the summer of 1856 on the basis of his work in plant pathology Kühn took his doctorate at Leipzig, and passed the examination for lecturer at the Agricultural Academy at Proskau. After one term there he again returned to the land, taking the management of a large estate near Gross-Glogau in lower Silesia. It was from here in 1858 that he published the first edition of his text-book on plant diseases. He remained on this estate until 1862, when he was called to the chair of Agriculture in the University of Halle, to begin his career as a university professor at the age of thirty-seven. Kühn married at the age of thirty-two and was the father of five children (Wohltman and Holdefleiss, 1905).

Kühn's first and only text-book on plant pathology appeared, as has been indicated, in 1858. So great was the demand for it that a second unaltered edition was published the next year. Although he wrote numerous articles on plant diseases from time to time until his death, he contributed more largely along other lines of agriculture. One of his best known works is that on cattle feeding, ${ }^{1}$ which, first published in 1861, ran through many editions.

The full title of Kühn's book ${ }^{2}$ on plant diseases is, Die Krankheiten der Kulturgewächse, ihre Ursachen und

${ }^{1}$ Kühn, J.: Die zweckmässigste Ernährung des Rindviehs vom wissenschaftlichen und praktischen Gesichtspunkte, Dresden, 1861.

${ }^{2}$ Kühn, J.: Die Krankheiten der Kulturgewächse, ihre Ursachen und ihre Verhütung, pp. I-XXII + 1-312, Berlin, 1858. 
ihre Verhütung (The diseases of cultivated plants, their cause, and their prevention). It is in several respects an epoch-making book. It is the first phytopathologic text to appear based upon the remarkable and farreaching discoveries and researches of de Bary, the Tulasne brothers, Pasteur, and other workers of the first half of the 18th century in the field of parasitology. Here for the first time in a phytopathologic text (excepting the little paper of Fabricius the Dane) is adopted the fundamental fact of the causal nature of fungi as pathogenes in the diseases of plants. With a fine grasp of the entire field of etiologic phytopathology Kühn, while recognizing the new factor, pathogenic fungi, did not deny the old and generally accepted factors of weather, soil conditions, animals, and parasitic flowering plants as producers of disease in plants. He accepted them, but gave them their proper place and value in his treatment of the subject. A brief of the table of contents of this the first of modern texts on plant diseases will best indicate the tremendous advance in the science during the first half of the 19th century:

\section{FIRST PART}

General considerations with respect to plant diseases. Introduction.

Nature and types of disease in plants.

Cause of disease:

Unfavorable climatic and soil conditions.

Diseases due to the influences of animals.

Diseases due to parasitic plants:

Phanerogamic parasites.

Cryptogamic parasites. 


\section{SECOND PART}

Special investigations on diseases of cultivated plants. The smuts of cereals.

The rust.

The ergot.

The mildew, sooty mold, and honey dew.

The leaf blight or leaf spot disease.

The disease of rape and rape seed.

The seed rot of Fullers' teasel and the gout or cockle disease of wheat.

The diseases of tuber and root crops.

\section{APPENDIX}

The microscope as a household utensil for the farmer.

In the case of those diseases especially investigated (as above indicated) methods of control based on a proper conception of the causal factors involved and thoroughly tested in actual practice by the author are recorded. This book is a model of conciseness and accuracy that has not been excelled by any of the numerous pathologists who have written books since that time. This is the great achievement of the father of modern plant pathology that he was the first to apply the scientific knowledge of his 'day to the practical solution of plant disease problems, and so fundamental has been this contribution of Kühn's that it has remained to the present time the vitalizing factor in the wonderful growth and development of the science.

In 1868 appeared the text-book "Phytopathologie,"1

${ }^{1}$ Hallier, E.: Phytopathologie. Die Krankheiten der Culturgewächse für Land- und Forstwirthe, Gärtner und Botaniker, pp. I-X + 1-373, 1868. 
by Ernst Hallier. This was the first text-book of any importance to follow that of Kühn's. As this was the only edition which he published, Hallier may, therefore be said to have belonged to this period alone; in fact, as we shall see, he retired from active work about the end of the period.

Ernst Hallier lived from 1831-1904. Beginning as assistant gardener in the Botanical Gardens at Jena in 1848, he later studied at the University of Berlin, taking his degree in 1858. He then became assistant to his uncle, Professor Schleiden, the botanist at Jena. Here in 1866 he was promoted to assistant professor, in which capacity he served for nineteen years, retiring on account of ill health in 1884. He is perhaps best known for his antagonism to and attacks upon de Bary, whom he hated. His failure to obtain a full professorship he blamed chiefly on de Bary, who, however, does not appear to have been responsible except perhaps indirectly as an opponent of his peculiar scientific ideas. Hallier's book was far more comprehensive and extensive than that of Kühn, but lacked the sound scientific and practical experimental basis of that master's work. The peculiar and erroneous ideas of the author with respect to the genetic relation of bacteria to fungi brought discredit upon the book among the scientific workers of his day. He believed that bacteria developed into fungi. His work, therefore, did not have a great influence on plant pathology.

Anders Sandфe Örsted, the most noted Danish plant pathologist before Rostrup, belongs to this period. He lived from 1816 to 1872 . His contributions to the science began about 1862 . Working with species of Gymnosporangium, he discovered heterœcism at about the same 
time and independently of de Bary. He is the author of several books and papers on the diseases of cultivated plants (Lind, $1913: 18,605,606$ ).

England made her first real contribution to the ranks of plant pathologists during the Kühnian period in the person of M. J. Berkeley. Receiving his inspiration and enthusiasm for the study of plants and their maladies largely from gardeners and horticulturists, his contributions to the science are largely addressed to the practical growers rather than to the scientists of his time. To the latter he was well known, however, as the leading English authority on fungi, and is generally held to be the founder of British mycology (Thiselton Dyer, 1897).

Miles Joseph Berkeley, born 1803, was one of the famous family of Berkeley. He was educated at Christ's College, Cambridge, from which he graduated in 1825 . In spite of his inclination for the natural sciences, he entered the then slightly more lucrative profession of the ministry, in which he continued until his death in 1889. $\mathrm{He}$ devoted all of his leisure to biologic studies and research, especially on fungi and plant diseases. Aside from numerous short papers on different plant diseases, his chief contribution to the science is that on vegetable pathology, ${ }^{1}$ which appeared in the Gardener's Chronicle throughout the years 1854 to 1857 inclusive. This extensive paper sets forth in much detail the ideas and theories with respect to diseases in plants held by English gardeners and scientists of that period. The chapter

${ }^{1}$ Berkeley, M. J.: Vegetable Pathology, Gard. Chron., 1854-1857, continued weekly throughout these years. See especially $1854: 4,20$ : $36,52,68,708,740 ; 1857: 644,660$, and the index, 676, 677 . 
on Diseases caused by fungi in his Outlines of British fungology ${ }^{1}$ gives an excellent picture of British knowledge of the subject at the opening of the Kühnian period.

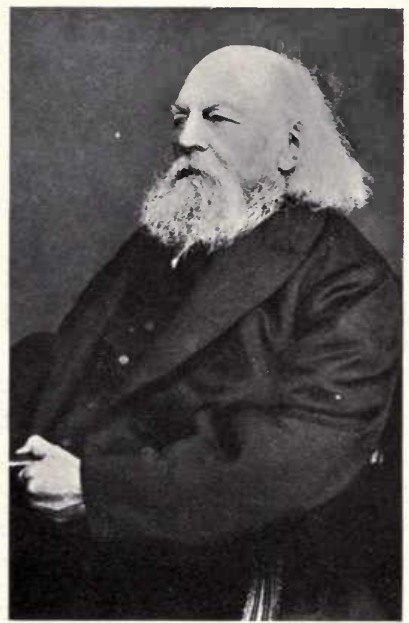

Miles Joseph Berkeley.

First noted English plant pathologist. (From a photograph, courtesy of Dr. L. R. Hesler.)

One of the best of his contributions, aside from those mentioned, is his paper on potato murrain ${ }^{2}$ which had

${ }^{1}$ Berkeley, M. J.: Outlines of British fungology containing characters of above a thousand species of fungi-and a complete list of all that have been described as natives of the British Isles, pp. I-XV + 1-442, London, 1860.

${ }^{2}$ Berkeley, M. J.: Observations, botanical and physiological, on the potato murrain, Jour. Roy. Hort. Soc. of London, 1 : 9-34, 1846. 
appeared in 1846. Berkeley is better known as a mycologist because of his numerous contributions in that field. He was always interested in the practical application of his knowledge, being for ten years editor of the journal of the Royal Horticultural Society.

Toward the end of this period appeared a number of books on plant pathology, for the most part the maiden efforts of young pathologists whose works and writings were to mold and direct in many ways the phytopathologic thought of the early part of the next period. The most important were: Important diseases of forest trees, $1874,{ }^{1}$ by Robert Hartig; Handbook of plant diseases, $1874,{ }^{2}$ and Fruit tree diseases, $1879,{ }^{3}$ by Paul Sorauer; and Diseases of plants, $1880,{ }^{4}$ by A. B. Frank. These men and their works will be discussed under the next period.

Summarizing as for the previous periods, we may say of the Kühnian period: (1) the thought and works of the time were decidedly mycologic; (2) the basis of classification was now entirely etiologic. This is characteristic of all the books on plant diseases published during this period; (3) the influence of the gardener, forester, and farmer was decidedly marked and was due primarily to the investigations of the farmer-scientist

${ }^{1}$ Hartig, R.: Wichtige Krankheiten der Waldbäume, pp. I-VIII + 1-127, Berlin, 1874.

${ }^{2}$ Sorauer, P.: Handbuch der Pflanzenkrankheiten, pp. I-VIII + 1-406, Berlin, 1874. This is the first edition, followed later by two enlarged revisions, the third in three volumes. (See footnote 1, page 100.)

${ }^{3}$ Sorauer, P.: Die Obstbaumkrankheiten, pp. I-VII + 1-204, Berlin, 1879.

${ }^{4}$ Frank, A. B.: Die Krankheiten der Pflanzen, pp. I-VII + 1-844, Breslau, 1880. 
Kühn. The attempt to serve this class of readers is indicated in the title of the books published; (4) the theory of the autogenetic origin of disease was almost completely discredited by the epoch-making discovery and demonstration of the causal nature of entophytic organisms, especially fungi, found associated with disease lesions. This doctrine of pathogene responsibility thus firmly established by the work of Pasteur, de Bary, Kühn, Hartig, and others was to inspire and shape the remarkable developments of the science during the succeeding period. Hallier sought in his treatment of the subject to counteract this to some extent by emphasizing the influence of soil, climate, and predisposition of the plant. Hallier's doctrine of predisposition was to be more ably developed by Sorauer during the next period, as we shall see; (5) control of plant diseases was for the first time placed upon a sound basis, made possible, of course, by the recognition of the true relation of fungi to plant diseases. Kühn's work on seed disinfection was the great achievement in this direction.

\section{THE MILLARDETIAN PERIOD}

The Millardetian or economic period extends from 1883 to about 1906 . This period is characterized by the emphasis that was placed upon the economic features of plant pathology. It was ushered in by a number of remarkable and far-reaching events and discoveries.

Discovery of Bordeaux Mixture.-A French pathologist, Millardet, with whose name this period is designated, began his experimental work with bordeaux 
mixture in $1883^{1}$ (Lodeman, $1896: 27$ ). Through his efforts its use was introduced throughout the vineyards of France, and the wine industry, threatened by the ravages of the American mildew fungus, was saved. This fungicide was shortly after introduced into America to be used for the same purpose, and also against the Phytophthora fungus on potatoes and the scab parasite of the apple. It soon became the universal fungicide, which place it held until the recent introduction of lime-sulfur as a summer spray. It still remains for the vine and potato as well as for many other plants the best and safest fungicide. The discovery and introduction of this mixture more than any other one thing influenced and shaped the development of the science of plant pathology during the quarter century following its discovery.

\section{Rise and Development of Plant Pathology in America.} - The national government had for some years maintained a Commissioner of Agriculture under whose direction were several sections or divisions, among them one known as the Botanical Division. On July 1, 1885, a Section of Mycology of the Botanical Division of the U. S. Department of Agriculture was established and F. Lamson Scribner appointed as the mycologist. Erwin F. Smith was called to be his assistant the following year, 1886. This represents the first government recognition of the science of phytopathology in this country,

${ }^{1}$ The discovery itself was made in October, 1882 , in a vineyard of St. Julian in Medoc. (See Jour. d'Agr. Prat., 1885, pp. 707-710, and also 801-805. There is a translation of the same article, U. S. Dept. Agr. Bot. Div. Sec. Pl., Path. Bul. 2, Appendix C, p. 94, 1886.) The first report of the discovery appears to have been made by Millardet in the Annales de la Societe d'Agriculture de la Gironde, 1885, p. 73. 
for the work had to do almost entirely with diseases in plants. In 1887 the name of this section was changed to that of Vegetable Pathology, Scribner continuing as chief. Scribner's reports for the years 1886 and $1887^{1}$ indicate the unorganized and dependent state of American phytopathology at that time. On November 1, 1888, there was appointed to this recently established section a young botanist who, under the stimulating influence of the discoveries of Millardet and of his own countrymen, was to stand forth as a leader in the development of phytopathology in America; I refer to B. T. Galloway, who succeeded Scribner in 1889.2 Galloway gathered about him gradually a staff of the most competent and enthusiastic young botanists of this country. Many of these became pathologists whose names and works are known today not only in their own country but in all foreign lands. One needs mention but a few of these to show the type: Erwin F. Smith, Merton B. Waite, David G. Fairchild, Mark A. Carleton, Walter T. Swingle, Herbert J. Webber, O. H. Dorsett, Newton B. Pierce, Albert F. Woods, and others. The influence of this division and its corps of workers upon the development of phytopathologic investigations in the various experiment stations of the different states was most potent. To their efforts was also due the founding of the present

${ }^{1}$ Scribner, F. L.: Report of the mycologist for the year 1886 . In, U. S. Dept. Agr. Ann. Report for the year $1886: 95-138$, 1887; also report of the chief of the section of vegetable pathology for the year 1887. In, U. S. Dept. Agr. Ann. Report for the year 1887 : I-V + 323397, 1888.

${ }^{2}$ Galloway, B. T.: Report of the chief of the section of vegetable pathology for the year 1888. In, U. S. Dept. Agr. Ann. Report for the year 1888 : I-IV + 325-404, 1889 (see p. 325). 
Bureau of Plant Industry of the U. S. Department of Agriculture. At present nearly every experiment station in the United States has a man or a number of men devoting a part or all of their time to plant disease investigation (Galloway, 1900 : 194-197).

\section{Discovery of the Bacterial Etiology of Certain Plant} Diseases.-During the years from 1878 to 1884 Burrill, in Illinois, working on the well-known fire blight of apples and pears, discovered that it was caused by bacteria. ${ }^{1}$ Wakker, a young Dutch pathologist, working on the so-called yellow disease of hyacinths, proved it to be caused by bacteria. He published his results from 1883-89.2 These studies were the beginning of a series of most remarkable discoveries of bacterial diseases in plants. Particularly numerous have been these discoveries in America, where this class of plant diseases has been brought to the fore through the remarkable investigations of Dr. Erwin F. Smith, who took up this line of work in 1893, publishing his first observations (on wilt of cucurbits) in that year. ${ }^{3}$

The first of these events forecasted the general character of the work and investigations of the Millardetian

${ }^{1}$ For a complete list of Burrill's publications on blight during this period, see bibliography in New York (Cornell) Agr. Exp. Sta. Bul. $329: 369,1913$.

${ }^{2}$ Smith, E. F.: The bacterial diseases of plants; a critical review of the present state of our knowledge, Amer. Nat., 30 : 797-804, 912-924, 1896. Uncompleted. (Gives an extended abstract of Dr. Wakker's papers.)

${ }^{3}$ Smith, E. F.: Two new and destructive diseases of cucurbits: 1. The muskmelon Alternaria. 2. A bacterial disease of cucumbers, cantaloupes, and squashes, Proc. Amer. Ass. Adv. Sci. for 1893, 42 : 259, 1894. Abstract Bot. Gaz., $18: 339,1893$. For further contributions on cucumber wilt, see Bacteria in relation to plant diseases, $2: 299,1911$. 
period. It was to be the economic period; the period in which the emphasis was to be especially placed upon the control of plant diseases. The importance of this phase of the science had been foreshadowed in the work and investigation of Kühn. Its importance during the Kühnian period was overshadowed by the researches and discoveries on the etiologic aspects of the science, as we have already seen. The economic importance of plant diseases became the dominating and vitalizing force in phytopathology during the Millardetian period. To the stimulating influence of the discovery of bordeaux mixture was added in the United States the stimulus of governmental sanction and support in the establishment in the U. S. Department of Agriculture of the section of Vegetable Pathology referred to above. Governmental espousal of scientific investigation always has been, and doubtless will be for many decades to come, based upon the economic value of the same. The etiologic phase of phytopathology which dominated the Kühnian period had its continuation and perpetuation during the Millardetian period chiefly in the discovery and unfolding of the causal relation of bacteria to plant diseases. While investigation and discovery in the realm of mycologic etiology was not halted or diminished, was, in fact, stimulated and expanded, nevertheless progress along these lines contributed largely to and was overshadowed by the progress in the control of the diseases of crops. The influence of bacterio-phytopathology on this progress and expansion was most marked and most healthful. Bacteriologic methods and technic were widely adopted and applied in the study of fungous pathogenes. Thus. it appears that these three factors-(a) discovery of the 
fungicide, bordeaux mixture; (b) governmental espousal of the science, and $(c)$ discovery of the bacterial nature of some of our most destructive plant diseases-combined to initiate a new epoch in the history of plant pathology.

A clear and comprehensive view of this period may best be obtained, perhaps, by a brief consideration, first, of the epoch-making discoveries and the men who made them, and, second, of the life and works of those phytopathologists who largely dominated the thought and teaching of the time.

The discovery of bordeaux mixture, as already pointed out, was the most potent factor in the development of the economic phase of plant pathology. It gave to the plant pathologist a means of control of wide application and remarkable efficiency. It became the universal fungicide. The active principle of this fungicide is copper. Numerous other copper fungicides were rapidly devised and exploited, such as ammonium copper carbonate, soda bordeaux, and eau celeste, but none of these were found to compare, in safety to the plants and in effectiveness against the fungi, with the bordeaux mixture originally devised by Millardet. As regards the control of plant diseases, this may well be regarded as the "copper" period. Of the man who first properly appreciated the fungicidal value of the copper salts, a few words are now in place.

Pierre Marie Alexis Millardet was born December 13, 1838, at Montmerey-la-ville in the department of Jura, and died December 15, 1902. Born of intellectual parents of old and honorable families, he was well taught and educated. He first studied medicine, but soon abandoned it for the more enticing pursuit of botany. 
Giving up the inheritance of the good medical practice of his uncle, he went to Germany to study botany first under Hofmeister at Heidelberg and then under de Bary at Freiburg. He was a profound student and an accomplished artist, his drawings being the admiration and envy of his fellow-students. Returning to France he

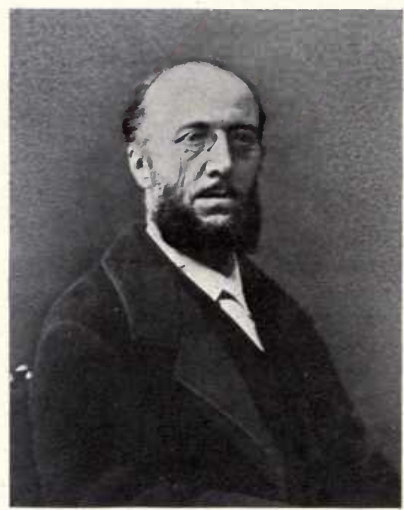

Alexis Millardet.

Discoverer of bordeaux mixture. (From a photograph, courtesy of Dr. Erwin F. Smith.)

took his doctorate in medicine and also in science. Immediately thereafter, 1869 , he was made assistant professor of botany in the University of Strassburg. The breaking out of the Franco-Prussian War the next year interrupted his work, and after serving in the army as surgeon he became professor of botany at Nancy in 1872, and finally professor of botany at Bordeaux in 1876, 
where he remained until his retirement in 1899, and where a monument has now been erected to his memory.

The early years of his professional life were given entirely to pure science. His later years and maturer judgment were devoted to the economic or applied phases of botany. This change in Millardet's line of thought and effort was determined by the introduction into France of two vine pathogenes from America, viz., the phylloxera and the downy mildew fungus, Plasmopara viticola. The former he had early studied to some extent in the laboratories of de Bary in Freiburg. The latter he discovered in France in 1878 at about the same time that a colleague, Planchon, found it in another part of the same country. Both these pathogenes spread rapidly and became so destructive as to threaten the wine industry of France. Millardet, already one of the. most noted botanists of France, was commissioned to investigate and combat these two threatening pests. By the introduction of resistant American vines as stock for the grafting of the European varieties he saved the vineyards from the phylloxera. Accidently observing the prophylactic effects against the mildew of a mixture of copper sulphate and lime sprinkled on grapevines along the road to prevent pilfering of the fruit, he discerned the possibilities of copper as a fungicide. He at once undertook the investigation of this mixture of lime and copper sulfate for the control of the devastating mildew and developed the bordeaux mixture (Lodeman, $1896: 25)$. This mixture has remained for a quarter of a century the most efficient and most universally applicable fungicide known. 
The discovery and establishment of the causal relation of bacteria to plant diseases, made during the first years of this period, was in many ways of even greater significance and importance than the discovery of the fungicidal value of copper. It is the greatest contribution to phytopathologic etiology since the epoch-making discoveries of de Bary and his contemporaries on the causal relation of fungi to plant diseases. The credit for this great discovery belongs to an American, Thomas J. Burrill. In justice to our European colleagues it must be recorded that working only a little later and independently a Dutch plant pathologist, J. H. Wakker, made a similar discovery (see footnote 2, page 61). Burrill, however, published his discovery first.

Thomas Jonathan Burrill, born in 1839 in Massachusetts, was educated at Illinois State Normal School. He held the honorary degree of Ph.D. from Chicago University (1881) and later the LL.D. from the Northwestern University. For many years he filled the chair of botany at the University of Illinois, and from 1879 until his retirement in 1913 was Vice-President of the University. He died in 1916. The discovery of the bacterial nature of the fire blight of pears and apples is but one, though unquestionably the greatest, of his several contributions to American botany and plant pathology. The details of his observations and experiments on the cause of fire blight are to be found largely in the papers he presented and the discussions in which he engaged before the Illinois Horticultural Society during the years from 1878-84 (see footnote 1, page 61). The reports of this society for these years will repay perusal. Of such great importance is this disease that following 
the pioneer investigations of Burrill, more extensive and detailed studies of the pathogene were undertaken by $\mathrm{J}$. C. Arthur, at that time, 1885 , botanist of the N. Y. (Geneva) Experiment Station, ${ }^{1}$ and by M. B. Waite of the U. S. Department of Agriculture. ${ }^{2}$ Many other workers in all parts of the United States and Canada have since

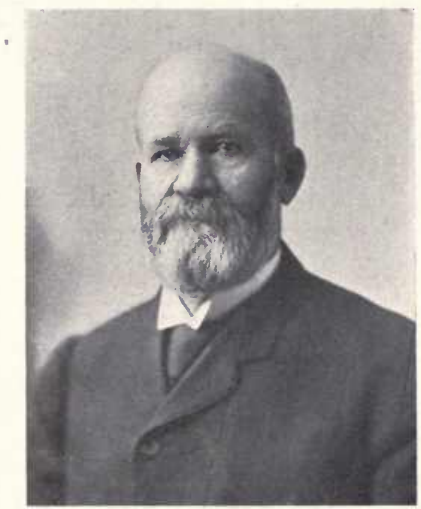

THOMAS J. BURRILL.

Discoverer of bacterio-phytopathogenesis. (From a photograph, courtesy of Dr. Erwin F. Smith.)

worked on the disease, so that we now possess a more extensive and better knowledge of the first recognized bacterial disease of plants than of almost any of the other numerous bacterial maladies since brought to light.

${ }^{1}$ For a list of Arthur's papers on pear blight, see New York (Cornell) Agr. Exp. Sta. Bul. $329: 368,1913$.

${ }^{2}$ Waite, M. B.: Cause and prevention of pear blight, U. S. Dept. Agr. Year Book 1895 : 295-300, 1896. 
Although the discovery by the Dutch pathologist, Wakker, of the bacterial nature of the yellow disease of hyacinths was announced shortly after the discoveries of Burrill on the fire blight, it appears to have had little attention from his European contemporaries, and the bacterial nature of plant diseases was an idea long unaccepted and vigorously combated by European botanists (Smith, Bacteria in relation to plant diseases, $2: 9-22$ ). At the time of his researches and discoveries on the yellow disease of hyacinths, Wakker was a young enthusiastic investigator in the University of Amsterdam. He had been especially employed by the bulb growers' association of Haarlem, Holland, to investigate this and other diseases at that time devastating their crops. Later he did some other excellent phytopathologic work, but failing of expected promotion at the University of Amsterdam, he foreswore botanical science and its devotees entirely, and sought solace in the teaching of mathematics in a secondary school. The loss to phytopathologic science of so brilliant and promising a worker is much to be deplored. His work, dealing with the yellow disease of hyacinths, has been carefully repeated and reviewed by Dr. Erwin F. Smith, and pronounced accurate and classical to a degree scarcely to be expected of the day in which Wakker worked. (See Smith, Bacteria in relation to plant diseases, $2: 336-337$, and U. S. Dept. Agr. Div. Veg. Phys. and Path. Bul. $26: 9,10$.

Great and epoch making as were these two discoveries, bordeaux mixture and bacterial phytopathogenes, the men who made them contributed but little else to the great progress and development of the science during this period. Millardet made some careful investigation; 
on Plasmopara viticola, and Burrill described one or more other bacterial diseases of plants, and made some worthy contributions to our knowledge of fungous pathogenes. Neither his training nor facilities permitted Burrill to develop and lead in the field of research on bacterial diseases of plants. This leadership, as we shall see, soon passed to another American. Moreover, both Burrill and Millardet devoted too great a portion of their time and efforts to teaching and administration to enable them to contribute largely to research in the field which their historic discoveries have so mightily influenced. Wakker's early self-elimination from the field we have already noted. These discoveries, however, together with governmental espousal of plant disease work inspired and stimulated a host of young men both in America and in Europe to take up phytopathology as a life work. The Millardetian period surpassed without doubt all previous periods in the number of workers and in the scope and variety of their efforts.

In America the beginning of this period found but very few old and well-trained botanists who were at all inclined to phytopathologic research. A few great teachers of botany, like Bessey, in Nebraska, Farlow, of Harvard, Burrill, of Illinois, Spaulding and Beal, of Michigan, and Tracy, of Missouri, recognizing the signs of the times, turned the eyes of their students to the opportunities in this direction. A little later to these were added the students of Atkinson, of Cornell, Thomas, of Wabash, Jones, of Vermont, and others who saw the economic trend and espoused it with enthusiasm. These young scientists with the pioneer spirit and enthusiasm of their fathers plunged into the problems with a vigor and 
earnestness that in twenty-five years has placed this country in the forefront of phytopathologic thought, research, and teaching.

In Europe the opening of this period found a considerable number of men, young but well trained, and already enlisted in the scientific work of phytopathology. As we have seen, some of these, like Hartig, Frank, and Sorauer, had during the last years of the Kühnian period made their first contributions to the science in monographs, manuals, and text-books. They brought to the new period minds trained and experienced in the field in which the problems were to be solved. They also brought with them the points of view and the prejudices of the previous period. They could not, from the very nature of the conditions under which they were trained and under which they worked, bring to their problems the enthusiasm and unbiased judgment of their American contemporaries. They were the direct inheritors of all the learning, the discoveries, and the dogmas in this field. Prior to 1880 plant pathology had been wholly European, one might almost say German. This inheritance was their handicap. Free from prejudice and dogma, unhampered by text and training, with all the problems before him new and untouched, the young pathologist of America delved with the energy and delight, and often, it must be admitted, with the recklessness and ill-preparedness of the pioneer. Much that was done was superficial, some of it was worthless. Yet so much of thoroughtly substantial and creditable research was accomplished as to force from some of our European contemporaries the not too ready or hearty acknowledgment of American leadership. 
Before passing to a brief consideration of the men whose work and researches stand forth from among the multitudinous contributions of this period, it may be pointed out that the Millardetian period saw the beginning of specialization within the science. From the general field were developed and split off in more or less independent lines of development forest pathology and bacteriophytopathology. Within the general field a tendency toward splitting up along crop group lines is also discernible, as, for example, diseases of fruit crops, diseases of citrus crops, diseases of field and garden crops, etc. This will be brought out more clearly in the discussion of the pathologists and their writings.

Modern pathologists may be divided, for the most part, into two philosophic schools, the pathogenetists and the predispositionists. The latter are the philosophic descendants of the autogenetists, of which Franz Unger and his period represent the highest development. The doctrine of this school collapsing before the revolutionary discoveries of de Bary, Kühn, and Pasteur, was maintained and somewhat readjusted to the new facts by Hallier during the Kühnian period. The pathogenetists and their doctrine of pathogene responsibility in plant disease production were distinctly the products of the Kühnian period. It will be recalled that, in reality, the first of these, Fabricius the Dane, had lived and announced the doctrine more than seventy-five years before the appearance of de Bary's classic work on the pathogenic nature of the smut fungi. But phytopathologic thought was at that time unprepared to understand and accept so revolutionary a doctrine. It remained for de Bary and Kühn to revive and prove it 
and to present it to a scientific public ready to receive it.

It is, therefore, not surprising that this doctrine so vitalizing and fruitful during the quarter century preceding should have seen a greater increase in its devotees during the Millardetian period. The discovery of so promising a fungicide as bordeaux mixture must needs be utilized. Known fungous pathogenes had to be more carefully studied. New ones were sought in connection with every disease of unknown etiology. The pathogenetists flourished. They dominated both as to numbers and influence in every land where plant diseases claimed attention. They were supported and strengthened by a host of enthusiastic mycologic contemporaries who had arisen as a result of de Bary's stimulating discoveries and teaching.

In Germany, the cradle of modern phytopathology, the most distinguished and influential of the pathogenetists were Hartig, Frank, Kirchner, Brefeld, and Klebahn. They entered the period as young but trained and seasoned recruits to the Kühnian standards. Of these, Hartig is the most renowned because of his pioneer and classic researches on the diseases of trees. He will live in the history of our science as the father of forest pathology. Of predispositionists, Sorauer stands forth without a peer, excepting only H. Marshall Ward of England.

Heinrich Julius Adolph Robert Hartig was born May 30, 1839, in Braunschweig, Germany. He was the last of an illustrious line of scientists. His grandfather, Georg Ludwig Hartig, chief forester of Prussia, laid the foundations of modern silviculture. His father, Theodor Hartig, a great forester of his time, was a botanist as 
well, and a student of tree diseases, especially wood decay. Living in the time and under the influence of the Ungerian period he misinterpreted the relation of the fungus mycelium to the decayed wood in which he was the first to record its occurrence. It remained for his son to make the correct interpretation. Robert Hartig received his early schooling in Braunschweig;

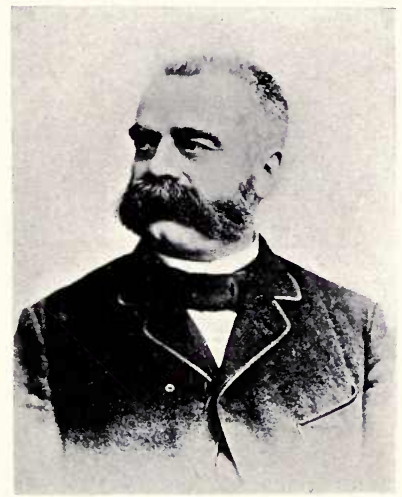

ROBERT HARTIG.

Father of forest pathology. (From a portrait in "Phytopathology," vol.v.)

spending much time with his father who was at that time in the forest service there. Trained as a professional forester, he was given his bachelor's degree at the age of twenty. He traveled through the forests of Germany for two years, served one year in the army, and finally went to the University of Berlin in the autumn of 1865 . Two years later he took his doctor's degree from the 
University of Marburg. He served in various positions in the Forest Service. In 1866 he was called to lecture on botany and zoölogy at the Forest Academy at Eberswalde, where he remained until 1878 , having been made professor of botany in 1871. From Eberswalde he was called in 1878 to the chair of botany in the royal Forestry Experiment Station at Munich, where he remained until his death, October 9, 1901, at the age of sixty-two.

The beginning of the Millardetian period found Hartig already firmly established in his life work. Two of his most classical contributions to our science had already appeared, viz., Wichtige Krankheiten der Waldbäume (1874) and Zersetzungserscheinungen des Holzes der Nadelholzbäume und der Eiche in forstlicher, chemischer, und botanischer Richtung (1878). The first edition of his Lehrbuch der Baumkrankheiten appeared the year of Millardet's famous discovery. Hartig appears to have been but little if at all influenced in his work and philosophy by the fungicidal trend and discoveries of the period. An etiologist of the de Bary school, he was little inclined to emphasize control. To the Millardetian period he gave rather than received; a product of the previous period, he became a molder of the etiologic thought of the new. He brought to this phase of our science a biologic and ecologic point of view of great worth and influence. Being a practical forester, he became a field pathologist. In the forest the numerous ecologic factors influencing disease phenomena are most in evidence. There he laid out his experiments and there he measured his results. His contributions from 1883 until his death eighteen years later are very numerous and important. $\mathrm{He}$ was a 
productive as well as an accurate, painstaking investigator. These contributions, while in large part phytopathologic, cover a wide range of forestry and botanical subjects, especially physiology and histology. Two new editions of his Lehrbuch appeared, the final one in 1900. Two translations of the earlier edition appeared in 1894, one in English and one in Russian. A French translation had been published in 1891. A classical work on the dry rot fungus of structural timbers (Der ächte Hausschwamm, Merulius lacrymans) appeared in 1885; another on smoke injury (Die Beschädigung der Nadelwaldbäume durch Hütten und Steinkohlenrauch) in 1896. He was engaged on a monographic study of lightning injury at the time of his death $(\mathrm{Tu}-$ beuf, $1903:(22)$ ).

Of the pathogenetists ranging the general field of phytopathology during this period in Germany, perhaps none is better known or had a wider influence, especially in Germany, than Frank. Trained as a plant physiologist, his early work was along the lines of physiologic biology. He made extensive studies on the biology of the legume organism and was the pioneer in the investigations of mycorrhizal fungi.

Albert Bernhard Frank was born January 17, 1839, in Dresden, where he received his early training in the Realschule and Gymnasium. In 1861 at the age of twenty-two he matriculated in the University of Leipsig, studying medicine and botany. He took his doctor's degree from Leipsig in 1865, at which time he was made curator of the herbarium, becoming shortly thereafter privatdocent, and finally in 1878 assistant professor of botany. Called to the chair of botany in the Agricul- 
tural College in Berlin in 1881, he remained there for eighteen years until his death, September 27, 1900. Born the same year as Hartig, he lived but one year less. Both were outstanding German pathogenetists of their time.

Frank's chief contributions to phytopathologic research were: (1) his discovery of the true cause of the leaf scorch of cherries, ${ }^{1}$ a disease which became epiphytotic in Germany about 1880 and threatened the destruction of all sweet cherry trees. He showed this to be due to the ascomycete Gnomonia erythrostoma which winters over on the leaves hanging to the tree. With German soldiers placed at his disposal he picked all these leaves for two seasons, claiming to have thereby effected the control of the disease; (2) his discovery of the cause of the heart and dry rot of sugar beets. ${ }^{2}$ This disease so threatening to the sugar-beet industry he showed to be due to the fungus Phoma bete.

Frank's career as a plant pathologist really began with his call to the chair of plant physiology in the Königlichen Landwirtschaftlichen Hochschule in Berlin in 1881, although the first edition of his text-book on plant diseases had appeared the year previous. The second edition of this text-book appeared in three volumes in $1895-96 .^{3}$

${ }^{1}$ Frank, A. B.: Über Gnomonia erythrostoma, die Ursache einer jetzt herrschenden Blattkrankheit der Süsskirschen im Altenlande, nebst Bemerkungen über Infection bei blattwohnenden Ascomyceten der Bäume überhaupt, Ber. Deut. Bot. Ges., 4 : 200-205, 1886; also, Uber die Bekämpfung der durch Gnomonia erythrostoma verursachten Kirchbaumkrankheit im Altenlande, Ber. Deut. Bot. Ges., 5 : 281-286, 1887.

${ }^{2}$ Frank, A. B.: Phoma Betae, ein neuer Rübenpilz, Zeitschr. Pflanzenkr., $3: 90-92,1893$.

${ }^{3}$ Frank, A B.: Die Krankheiten der Pflanzen, $1:$ I-XII + 1-344, 1895; 2 : I-XI + 1-574, 1896; 3 : I-IX + 1-363, 1896. 
Like Hartig, he was a product of the Kühnian period. As a professor in the agricultural college at the national capitol he was much in demand as lecturer before agricultural societies (Landwirtschaftliche Vereinen). $\mathrm{He}$ was vice-president of the Special Committee of the Imperial Government on plant protection. He was, on the whole, a teacher rather than an investigator. He is the author of no less than eleven text-books on botany, plant physiology, and plant pathology. He was secretary of the Deutschen Botanischen Gesellschaft from its foundation. He gave much of his time to what we would now designate as extension work. Frank's influence was greatest during his lifetime and in his own country. His work lacks that accuracy, finish, and touch of genius so characteristic of his countryman and contemporary, Robert Hartig.

Oskar Kirchner, the third German pathogenetist who belongs distinctly to the Millardetian period, still lives and works at his post in the agricultural college at Hohenheim in the hills to the south of Stuttgart in Wurtemberg, south Germany. A day with him in his laboratory and home during the winter of 1913 revealed something of his character and relation to phytopathologic science. A fine old man of perhaps sixty-five, with white hair and beard, he nevertheless exhibits every evidence of vigor and energy. A personality at once impressive and cordial, one sees in him the teacher rather than the investigator, but he is both. Like Frank, Kirchner emphasizes the practical applications rather than the scientific aspects of the science. His chief contributions to plant pathology are two: his text-book on the diseases of cultivated plants; and an 
atlas of colored plates illustrating the diseases and injuries of cultivated plants. The text-book, first published in $1890,{ }^{1}$ is designed primarily for farmers and gardeners. It is unique in the arrangement of its data, being, in short, an annoted key to the fungous diseases and insect injuries of plants, based on the symptoms exhibited.

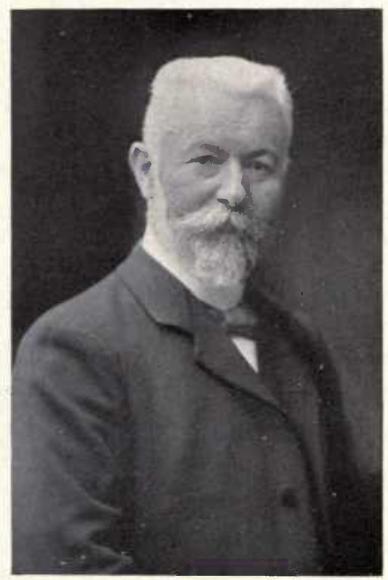

OSKar KirchNer.

A noted German pathogenetist. (From a photograph.)

The primary grouping of the diseases, is however, on the crop basis. There are ten groups or classes of these, as follows: 1. Cereals. 2. Edible-seeded legumes. 3. Fodder grasses. 4. Fodder legumes. 5. Root crops.

${ }^{1}$ Kirchner, Oskar: Die Krankheiten und Beschädigungen unserer landwirtschaftlichen Kulturpflanzen, pp. I-X + 1-637, 1890. A second completely revised edition appeared in 1906. 
6. Trade crops. 7. Vegetable and garden crops. 8. Tree fruits. 9. Small fruits. 10. Grapes. These are again divided into the individual crops composing each crop group and under each plant, according to the parts affected, as, for example, wheat: I. Diseases and pests of the heads. II. Diseases and pests of the leaves and haulms. III. Diseases and pests of the seedling. IV. Diseases and pests of the roots. V. Diseases and pests of the ripe seed. Finally, under each of these the diseases are arranged according to the chief symptoms exhibited. The atlas published in collaboration with $\mathrm{H}$. Boltshauser has appeared in several series beginning in 1896. ${ }^{1}$ Each colored plate, reproduced from large hand-painted charts, many of which he showed me with much pride, is accompanied by a brief text of description or explanation.

Germany produced during this period another pathogenetist of marked ability and who fortunately is still living and contributing to the etiologic phase of the science. I refer to Heinrich Klebahn, botanist of the Hamburg Botanical Institute. He is best known for his contribution to our knowledge of the heterœcious rusts. ${ }^{2}$ His first paper, published in 1887 , deals with a rust fungus. Since $1892^{3}$ he has published almost annually reports of his cross inoculation work with heterœcious

${ }^{1}$ For a list of these series see Lindau and Sydow, Thesaurus, $1: 767$. They appeared under the general title of Atlas der Krankheiten und Beschädigungen unserer landwirtschaftlichen Kulturpflanzen. Each series deals with the diseases and pests of some crop group, as, for example, "Krankheiten und Beschädigungen der Getreidearten."

${ }^{2}$ Klebahn, H.: Die wirtswechselnden Rostpilze. Versuch einer Gesamtdarstellung ihrer biologischen Verhaltnisse, pp. I-XXXVII + 1-447, Berlin, 1904.

${ }^{3}$ Klebahn. H.: Kulturversuche mit heteröcischen Uredineen, Zeitschr. Pflanzenkr., 2 : 258-275, 332-343, 1892. 
rusts. These reports have appeared in the Zeitschrift für Pflanzenkrankheiten. He stands in much the same relation to rust work in Germany that Dr. J. C. Arthur does to rust work in America. It is interesting to note in passing that not only are their contributions to phytopathology of a very similar type, but their personal resemblance to each other is marked. Klebahn's contributions, however, have not been confined to the rust diseases. He has done pioneer work on the diseases of tulips, lilacs, and celery due to other forms of fungi. An examination of the very extensive lists of his publications as given by Lindau and Sydow in Thesaurus 1 and 3 will best serve to impress one with the range and volume of this man's contributions to the phytopathologic thought of his time. His text-book on the Basis of general phytopathology appeared in 1912. ${ }^{1}$ In the point of view therein expressed and in its treatment of the material it is distinctly of the Millardetian period.

Of the life and training of Klebahn no data have been available to the writer. A morning spent with him in his laboratories and gardens in Hamburg in the spring of 1914 has left a most pleasant impression of the personality, ability, and scientific spirit of the man. He is wholly an investigator, keen, and as critical of his own work as he is of that of his contemporaries.

There are numerous other German workers of the pathogenetist school belonging to the Millardetian period. Space permits the mention of but one other, Oskar Brefeld. While perhaps more truly a mycologist than any of his countrymen above discussed, his work

${ }^{1}$ Klebahn, H.: Grundzüge der allegemeinen Phytopathologie, pp. 1-147, Berlin, 1912. 
has nevertheless a marked phytopathologic character. His most noteworthy contributions to mycology began to appear about 1872 under the general title of Untersuchungen aus dem Gesammtgebiet der Mykologie (See Lindau and Sydow, $1: 196 ; 3: 120$ ). Among the studies detailed in the fourteen quarto volumes which have appeared up to 1908, those dealing with the smut fungi are of the most value to phytopathologic science. Of special importance have been the studies on corn smut and on blossom infection by the loose smut fungi of cereals. So far as the writer is aware, Brefeld still lives, and there is no data at hand for a biographic sketch. A chronologic arrangement of his contributions indicate clearly that he belongs to the Millardetian period. His relation to plant pathology is much the same as that of de Bary, a builder of one of the fundamental foundations of that science rather than of the superstructure itself.

Other European countries contributed pathogenetists to this period less in number, but equally eminent with those of Germany.

One of the most interesting of the non-German pathogenetists is the Danish botanist, Rostrup. He was one of the most diligent, broad-minded, and successful plant pathologists of this period. Because he wrote almost wholly in Danish his work is little known outside of the Scandinavian countries. Lind $(1913: 25)$ calls him the "first phytopathologist of Denmark." For years a teacher of mathematics and natural history in a secondary school, he trained himself in botany and mycology during leisure hours, so that at the age of forty he was the accepted authority on the flowering plants and fungi 
of Denmark. Naturally inclined to the practical applications of his scientific knowledge, he then turned his attention to the diseases produced by fungi in plants, and during the next thirty years of his life won for himself and his little country an enviable place in the history of plant pathology. As a mycologist his name is perpetuated in a gigantic collection of over 30,000 specimens of Danish fungi, now preserved in the botanical museum of the University of Copenhagen. The one thing to make this monument complete we now have - the fine volume (in English) on Danish Fungi by J. Lind, which is based upon this collection. As a phytopathologist his great contribution to literature is his comprehensive work, Plantepatologi, ${ }^{1}$ published in his seventy-second year, a text-book of phytopathology based on the study and experience of over thirty years devoted to the subject of plant diseases. Ravn says of this book: "It is a book the distinctive exterior of which bespeaks the sterling and personal character of its contents. The series of different disease types stand sharply forth with exact clearness. One feels that he has here to do with proved experience. The work shows throughout the characters of reliability. It takes a prominent position in the world's literature" (1909:50).

Frederick George Emil Rostrup was born January 28, 1831, on the island of Lolland. Ravn's brief statement of his early life and boyhood training reads wonderfully like that of Julius Kühn. The son of a farm-manager of a large estate, he received his early education in the public schools. Fond of hunting, he soon became inter-

${ }^{1}$ Rostrup, E.: Plantepatologi, Haandbog i Leren om Plantesygdomme for Landbrugere, Havebrugere og Skovbrugere, pp. I-V + 1-640, 1902. 
ested in the natural history of the game he sought, especially birds. After a year as secretary to his father he went, at the age of nineteen, to Copenhagen, where he studied natural history and mathematics in the Polytechnical School and in the University. Here for seven years he studied, getting the best the University had to

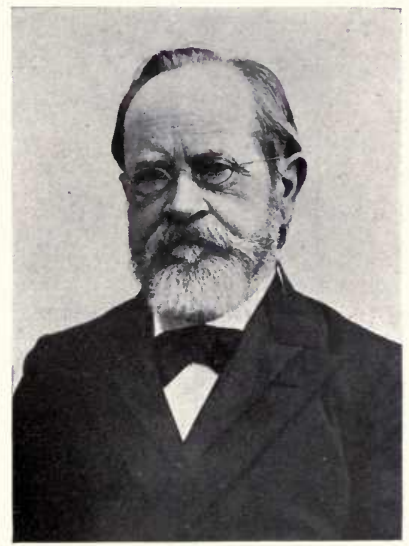

EMIL Rostrup.

The most noted Danish phytopathologist. (From a portrait in "Botanisk Tidiskrift," vol. xxviii.)

offer in mathematics and natural history, especially botany and agriculture. Having passed his final examinations, he accepted, at the age of twenty-six, the position of teacher in mathematics and natural history at the public seminary at Skaarup in southern Fünen. Here he lived and taught for twenty-five years. It was during the leisure of these years that he made himself both a 
phaneogamic botanist and a mycologist of renown. His interest in mycology dates from August 31, 1860, the date of his first collection of fungi. In 1860 he published the first edition of his Flora of Denmark (including only flowering plants), which has already gone through ten editions, and is to Danish botanists what Gray's Manual is to Americans. In 1869 he published a second volume of this flora dealing with the Cryptogames (Ravn, 1909 : $47-55)$.

His interest in phytopathology as such dates from 1870 . The works of Kühn, de Bary, and Tulasne were the sources of his inspiration and teachings, while the wealth of his knowledge and experience with the flowering plants and fungi made these teachings more fruitful than usual. His first publications on the diseases of cultivated plants began to appear in 1870-71. Becoming especially interested in diseases of trees, he became an intimate correspondent and contemporary worker with Robert Hartig. His greatest contributions are, according to Ravn (1909:49), in the field of forest pathology.

During the decade 1870 to 1880 Rostrup's phytopathologic work developed and attracted such general attention throughout Denmark, especially among farmers, that in 1883 he was called to the Agricultural College as instructor in plant pathology and chief consulting plant pathologist for the national government. In 1889 he was made lecturer, and finally in 1902 professor, at the age of seventy-two. He died January 16, 1907, at the age of seventy-six. Probably no one man has so completely dominated by his life and works the botanical and agricultural thought of an entire country. 
It will be seen from the above that Rostrup, the phytopathologist, was distinctly of the Millardetian period, though, like his European contemporaries, Hartig, Sorauer, and Frank, he brought to his work a training and point of view fashioned and fixed in the atmosphere of the Kühnian period. He began officially his professional career as a pathologist in that year which marks the beginning of the Millardetian period. His textbook on plant pathology appeared during the very last years of the period (1902).

Rostrup's contributions to phytopathologic science consist not alone in published papers. He has left behind a corps of enthusiastic and well-trained young pathologists, his students, who are carrying forward with remarkable energy and brilliancy the work he has so well established. The most noted of these is his successor at the agricultural college of Copenhagen, F. K $\phi$ lpin Ravn.

There were during this period but two other plant pathologists in Denmark who, according to Lind (1913:25), deserve to be mentioned with Rostrup. These are P. Nielson and J. L. Jensen. Both were noted for their practical applications of Rostrup's ideas to the control of plant diseases. Jensen is especially noted for his investigations on the control of cereal smuts by the hot-water method and on the control of the late blight of potatoes (Ravn, $1917: 1-4$ ).

Scandinavia produced during this period another plant pathologist of eminence and a striking type of pathogenetist in Jakob Eriksson of Sweden. As he is still living the facts regarding his early life and training are not available in a published biography. His contributions show, however, that he was a contemporary of 
Rostrup. Prominent in the agricultural activities of his country, he was for many years professor and director of the Botanical Division of the Swedish Central Station for Agricultural Experiments in Stockholm. He has recently retired.

Eriksson has devoted himself primarily to the diseases of cereal crops, especially the rust diseases; his most

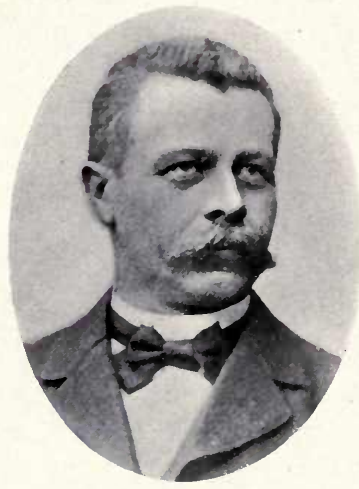

JAKOB ERIKSSON.

Most noted Swedish phytopathologist. (From a portrait in Wittrock's "Acta Horti Bergiani.")

important contribution along this line being the work on cereal rusts, published in 1896 with E. Henning as coauthor. ${ }^{1}$ It is a volume of 464 pages with fine colored plates.

To Eriksson belongs the credit of having discovered

${ }^{1}$ Eriksson, J., and Henning, E.: Die Getreideroste, ihre Geschichte und Natur, sowie Massregeln gegen dieselben, pp. I-VIII + 1-464, Stockholm, 1896. This was first published in 1894 in No. 38 Meddelanden frän Kongl. Landtbruks Akademiens Experimentalfält. It was translated from the Swedish into German by C. O. Nordgren. 
biologic races or "special forms," as he called them, within morphologic species of rusts. ${ }^{1}$ This has been one of the very fruitful discoveries in phytopathologic etiology during the Millardetian period and has been extended to other groups. Eriksson is widely known as the author of the mycoplasm theory. This theory is one of the most extraordinary and ingenious modifications of the idea of symbiosis which any botanist has proposed. The gist of the mycoplasm theory is that the naked protoplasm of the pathogene lives for a time mingled in indistinguishable combination with that of the host. This mixed plasm Eriksson designates as mycoplasm. He holds that at certain stages in the host's development the pathogene protoplasm separates itself from that of the host, migrates through the cell walls out into the intercellular spaces, at first a naked nucleated mass not unlike a plasmodium. Gradually this takes on a threadlike shape, secretes a cell wall, and sends haustoria into the adjacent cells, and the pathogene mycelium is formed. From this internal mycelium, present throughout the plant, spore bodies arise beneath the epidermis simultaneously. Thus he accounts for the sudden and general outbreaks of rusts. The pathogene reverts to the mycoplasmic condition in the next crop of seeds and is thus perpetuated. ${ }^{2}$ Eriksson has persisted in main-

${ }^{1}$ Eriksson, J.: Ueber die Specialisirung des Parasitismus bei den Getreiderostpilzen, Ber. Deut. Bot. Ges., 12 :292-331, 1894; also Neue Untersuchungen über die Specialisirung, Verbreitung und Herkunft des Schwartzrostes (Puccinia graminis Pers.), Jahrb. Wiss. Bot., 29 : 499524, 1896.

${ }^{2}$ Eriksson, J.: Über die Mykoplasmatheorie, ihre Geschichte und ihren Tagesstand, Biol. Centralbl., $30: 618-623$, 1910. (A concise review of the matter with numerous references to the literature of the subject.) 
taining his theory in the face of withering attacks upon it by the English mycologist, H. Marshall Ward, ${ }^{1}$ and by others. He has recently sought to strengthen his position by an extensive study of the hollyhock rust, Puccinia malvacearum, in which he assumes to have discovered another marked case of rust inheritance through mycoplasm. ${ }^{2}$ Eriksson is the author of a text on the fungous diseases of field crops, the first of a projected series on the fungous diseases of the cultivated plants of Sweden. ${ }^{3}$

Russia's contribution to the ranks of the pathogenetists was Woronin. He was a mycologist rather than a pathologist. A single contribution, his studies on the club root of cabbage, ${ }^{4}$ alone suffices, however, to give him a place among plant pathologists.

Michael Stepanovitch Woronin was born in St. Petersburg June 21, 1838, a year after the birth of Hartig. Born of wealthy parents, he was not only well educated but also inherited wealth which made him independent throughout a life almost entirely devoted to investigation. Entering the University of St. Petersburg at the

${ }^{1}$ Ward, H. M.: II. On the histology of Uredo dispersa Erikss. and the "mycoplasm" hypothesis, Phil. Trans. Roy. Soc., London, B: 196 : 29-46, 1904. (Read March, 1903.)

${ }^{2}$ Eriksson, J.: Der Malvenrost (Puccinia malvacearum Mont.), seine Verbreitung, Natur und Entwickelungsgeschichte, Kungl. Svenska Vetenskapsakademiens Handlingar, $47: 2: 1-125,1911$.

${ }^{3}$ Eriksson, Jacob: Landtbruksväxternas Svampsjukdomar, pp. I-XII + 1-210, Stockholm, 1910. This is the first part of his Vara Kulturväxters Svampsjukdomar (Diseases of our cultivated plants). An English translation of this by Anna Molander was published in 1912 under the title: Fungoid diseases of agricultural plants. A German translation by A. Y. Grevillius appeared in 1913.

${ }^{4}$ Woronin, M.: Plasmodiophora Brassicae. Urheber der Kohlpflanzen-Hernie, Jahrb. Wiss. Bot., 11 : 548-574, 1878. 
age of sixteen, he took his bachelor's degree in four years, after which he studied in Germany under de Bary, from whom he received his greatest inspiration and his tendency toward mycologic studies. Not caring to seek a Ph.D., it was thrust upon him eventually in 1874 by the University of Odessa, honoris causa. From 1869

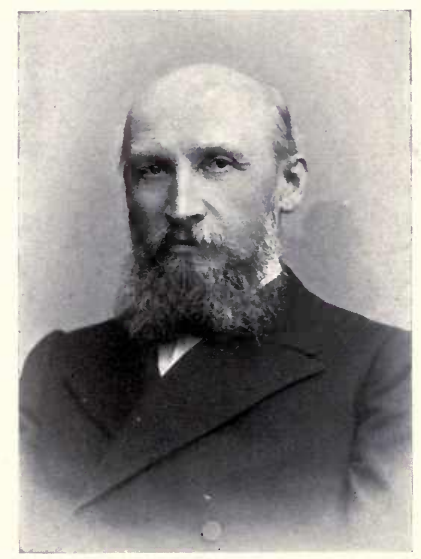

Michael Woronin.

The greatest of Russian phytopathologists. (Frcm a photograph, courtesy of Dr. Erwin F. Smith.)

until his death, February 20, 1903, he lived in St. Petersburg, teaching mycology and cytology for a time, but devoting himself during his latter years entirely to research as a member of the Royal Academy of Sciences.

A man of rare ability and attainments, he was possessed of a fine and lovable personality. Famintizen, his colleague and biographer, says of him: "Vanity, 
egotism, and human malice, the traits common to most of us, were unknown to him" (Smith, 1912:4). His bedroom was ever his laboratory. His microscope, a few simple tools, his pencil and paper, on a small table by the window near his bed, sufficed as equipment with which he turned out those classical monographs which have made him famous throughout the botanic and mycologic world. These studies were, like those of de Bary, of fundamental significance for phytopathologic science. The most important of these, aside from the one already mentioned, are his studies on Sclerotinial diseases of fruits, especially the one on Sclerotinia cinerea and Sclerotinia fructigena, ${ }^{1}$ and on the sunflower rust pathogene, Puccinia Helianthi. ${ }^{2}$

Phytopathology in Holland during the Millardetian period was represented chiefly by the pathogenetist, J. Ritzema Bos. He was the first director of the privately endowed Wille Commelin Scholten Phytopathological Laboratory, established in Amsterdam in 1895 (RiztemaBos, 1906 : 28-58). In 1906 he was called to take the directorship of the Government Institute for Phytopathology at Wageningen, of which he is still the active head (RitzemaBos, $1906: 17-27)$. He is perhaps best known as the editor of the Dutch journal on plant diseases, Tijdschrift over Plantenziekten, ${ }^{3}$ the first issue of which appeared in 1895.

${ }^{1}$ Woronin, M.: Über Sclerotinia cinerea und Sclerotinia fructigena, Mem. Acad. Imp. Sci., St. Petersbourg, VIII. Ser. Phys. Math. Cl., $10: 5: 1-38,1899$.

${ }^{2}$ Woronin, M.: Untersuchungen über die Entwickelung des Rostpilzes (Puccinia helianthi), welcher die Krankheit der Sonnenblume verursacht, Bot. Zeit., 30 : 677-683, 693-697, 1872.

${ }^{3}$ Tijdschrift over Plantenziekten, edited $1895-1903$ by J. Ritzema Bos and G. Staes; 1904 to date, by J. Ritzema Bos alone. 
England contributed to this period but two plant pathologists of note- H. Marshall Ward and D. McAlpine. Ward, because of his physiologic training and point of view, is to be classed with Sorauer as a predispositionist. McAlpine, on the other hand, is shown by his work to be an orthodox pathogenetist.

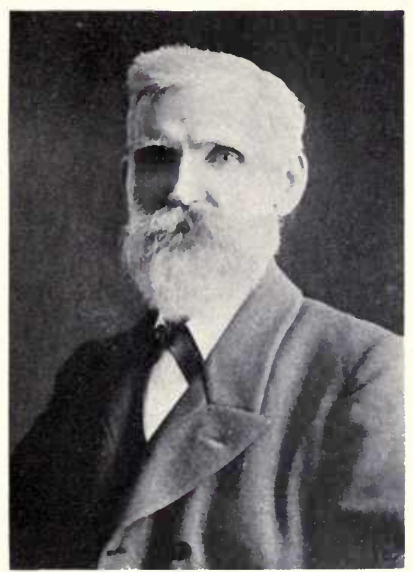

DANiel McAlpine.

Noted Australian plant fathologist. (From a photograph.)

Daniel McAlpine, vegetable pathologist to the Department of Agriculture of Victoria, Australia, though trained in England, has made his reputation entirely through his lifelong labors in the Australian commonwealth. His work on the fungous diseases of Australian crops and native plants, especially his monographs of the rusts and the smuts, are well known to his contemporaries through- 
out the world. ${ }^{1}$ He has recently completed the fifth volume of a most extensive investigation on the nature and control of the bitter pit (stippin) of the apple. ${ }^{2}$ This work, undertaken in 1911, is of a type very different from that of his previous contributions. It is distinctly physiologic, being in sharp contrast to the mycologic character of his earlier contributions. This work on bitter pit will doubtless give McAlpine a place in the present era. Born in Scotland and educated in London University, he went, in 1884 at the very beginning of the Millardetian period, to Australia, where he held the position of lecturer in biology in Ormond College and at the same time a similar position in botany in the College of Pharmacy in Melbourne until 1890, when he was appointed to his present position.

The most noted Hungarian phytopathologist of the Millardetian period is Gyula de Csik Madejalva Istvanffi, director of the Royal Central Institute for Viticulture at Budapest. He has made extensive studies of the more common diseases of the grape. ${ }^{3}$ He is still living, hence

${ }^{1}$ McAlpine, D.: The rusts of Australia, pp. 1-349, 1906; and The smuts of Australia, pp. 1-285, 1910. He has to his credit a total of over 220 scientific books and papers, of which 15 are scientific contributions of special merit. For an extensive list of his contributions see, List of Scientific Works, Papers, and Bulletins by D. McAlpine, government vegetable pathologist 1877-1916, in an unnumbered pamphlet, pp.1-12, 1916. Published by Department of Agriculture of Victoria, Melbourne, Australia.

${ }^{2}$ McAlpine, D.: Bitter pit investigations, Reports 1-5, 1911 to 1916.

${ }^{3}$ Among Istvanffi's most important papers on grape diseases may be mentioned, Ėtudes microbiologiques et mycologiques sur le rot gris de la vigne (Botrytis cinerea, Sclerotinia Fuckeliana), pp. 183-360, 1905; Études sur le rot livide de la vigne (Coniothyrium Diplodiella), pp. 188, 1902; Études sur le mildiou de la vigne, pp. 1-125, 1913; all published in the Annales de l'Institute Central Ampélologique Royal Hongrois. 
little biographic data is available. His contributions show him to belong to the dominating school of the Millardetian period.

The Latin races have had much less influence on phytopathology than have the Teutonic and Anglo-Saxon. Nevertheless, during the Millardetian period, France and Italy produced plant pathologists of note. They are chiefly pathogenetists. Most of these are still living.

In France, aside from Millardet, the most noted pathogenetists of this period are Delacroix, Prillieux, and Viala. These men all began their work in the field of plant pathology about the opening of the period. Prillieux had already made some contributions to the science as early as 1872 . Viala, whose first paper appeared in 1883 , has devoted himself almost entirely to diseases of the vine. (See list of his papers in Lindau and Sydow, 2 : 692-695.)

Edouard Ernest Prillieux has made perhaps the most numerous and varied contributions to French literature on plant diseases. He was for many years professor of botany at the Institute Agronomique in Paris. He died in 1915 at the advanced age of eighty-seven. He was a senator and the first director of the laboratory for vegetable pathology in Paris. Prillieux is regarded by his French contemporaries as the founder of phytopathology in France. He is the author of a two-volume work on diseases of agricultural plants, published in 1895 and 1897. Many of his papers were published in co-authorship with Georges Delacroix. Upon his election as

${ }^{1}$ Prillieux, E.: Maladies des plantes agricoles et des arbres fruitiers et forestiers causées par des parasites végétaux, 1: I-XVI + 1-421, $1895 ; 2: 1-592,1897$. 
Senator in 1897 he was forced to give up the chair of botany which he had occupied since its creation.

George Delacroix was born in 1858 in Paris. The second of six children of a poor family, he suffered great hardships and privations in his struggle to get an education and fit himself for the profession of medicine. While still a student he exhibited a great interest in botany and

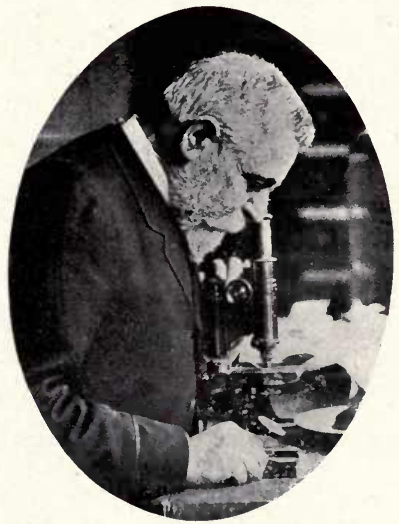

Edouard Prillieux.

Founder of phytopathology in France. (From a portrait in "Bulletin de la Société Mycologique de France," vol. xxxii.)

was able during the years of his struggle as a young physician to find time for botanical excursions with the noted mycologist Boudier. In this way he acquired an extensive knowledge of the fungi. In 1888 he was offered a position with Prillieux as assistant in the laboratory of Plant Pathology in the Institut Agronomique, which he accepted. On the retirement of Prillieux in 1897 he was 
made director of the newly established Station of Plant Pathology, in which position he continued until his death. $\mathrm{He}$ is especially noted for his studies on the diseases of tobacco. He also gave much attention to the diseases of tropical plants, material of which came to him from the French colonies. In addition to his numerous papers on various diseases of plants, Delacroix is the author of

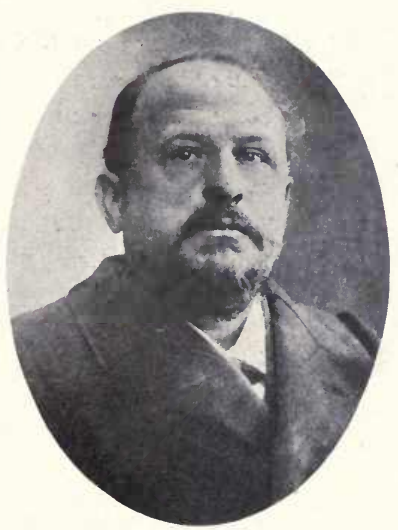

Georges Delacroix.

A noted French pathogenetist. (From a portrait in "Bulletin de la Société Mycologique de France," vol. xxiv.)

several text-books. The first of these, a small booklet on diseases of cultivated plants, appeared in $1902 .{ }^{1}$ A book on non-parasitic diseases of plants was given to the public in 1908 after his death. ${ }^{2}$ He wrote the final pages

${ }^{1}$ Delacroix, G.: Maladies des plantes cultivées, pp. 1-73, Paris, 1902.

${ }^{2}$ Delacroix, G.: Maladies des plantes cultivées. Maladies non-parasitaires, pp. I-XII + 1-431, Paris, 1908. 
of this work the evening before he died. His most pretentious text, that on the diseases of plants of the tropics, ${ }^{1}$ was completed by his successor, Maublanc, from notes and manuscripts which he left.

Italy produced several plant pathologists of note during this period. Orazio Comes, born in 1848, was at the opening of the period the most mature and best known. He had already published numerous papers on pathogenic fungi, including an extensive text on the cryptogamic parasites of agricultural plants. ${ }^{2}$ A second book on the same subject appeared in $1891 .^{3}$ He has written extensively on the diseases of the vine. His most recent contributions to the literature is a text on the control of plant diseases. ${ }^{4} \mathrm{He}$ is one of the most productive teachers of phytopathology in Italy, his students occupying many positions throughout the kingdom. Formerly professor of botany in the Royal School of Agriculture at Portici, he is now director of that institution.

Of the Italian plant pathologists of the Millardetian period, perhaps the most noted is Luigi Salvatore Savastano, whose first papers appeared about 1881. He was born in Naples in 1853 and is still living. He was for some years professor of arboriculture and applied vegetable pathology in the Superior School of Agriculture

'Delacroix, G.: Maladies des plantes cultivées dans les pays chauds, pp. I-IX + 1-595, 1911.

${ }^{2}$ Comes, O.: Le Crittogame parassite delle piante agrarie. Lezioni tenute nella R. Scuola Sup. die Agric. di Portici nell'anno 1882 : 1-580, Napoli, 1882. This consists of a collection of his lectures, reproduced in script from a copy made by his students, R. de Netto and F. de Rosa; illustrated by another student, L. de Luise.

${ }^{3}$ Comes, O.: Crittogamia agraria, pp. 1-600, Napoli, 1891.

'Comes, O.: La profilassi nella patologia vegetale, pp. 1-172, Napoli, 1916. 
at Portici. He is at present director of the Royal Experiment Station for the culture of citrus and other fruits at Acireale. Among his numerous contributions to phytopathology the following merit special mention: (1) various papers on the olive knot, a bacterial gall' (2) a book on the diseases of trees ${ }^{2}$; and his essay on the phytopathology of the Greeks, Romans, and Arabs. ${ }^{3}$

Fridiano Cavara, director of the Royal Botanical Gardens at the University of Naples, has made many contributions since 1888 to Italian phytopathologic literature. According to Smith, ${ }^{4}$ Cavara was the first to isolate the crown gall organism and make successful inoculations with it. These investigations were made on the crown gall on grapes and published in 1897.5

Augusto Napoleone Berlese is another Italian pathogenetist of this period who deserves mention. His first publication on fungi appeared in 1883 (Lindau and Sydow, Thesaurus, $1: 135$ ). He is perhaps best known as one of the editors of Rivista di Patologia Vegetale, which began to appear in 1892. He died in 1903.

We must now turn to a consideration of that other

${ }^{1}$ Savastano, Luigi: Tuberculosi, iperplasie e tumori dell'olivo. I-II Memoria, Ann. R. Scuola Sup. Agr. in Portici 5 : 1-131, 1887. See also Smith, Erwin F., Recent studies of the olive tubercle organism, U. S. Dept. Agr. Bu. Pl. Ind. Bul. 131 : 25-43, 1908.

${ }^{2}$ Savastano, Luigi: Patologia arborea applicata; lezioni, pp. I-XI + 1-666, Napoli, 1910.

${ }^{3}$ Savastano, Luigi: La patologia vegetale dei Greci, Latini ed Arabi; memoria, pp. 1-75. Portici, 1890; from Scuola Sup. Agric. Portici Ann., VI, $1890-91$.

${ }^{4}$ Smith, Erwin F., et al: Crown gall of plants; its cause and remedy, U. S. Dept. Agr. Bu. Pl. Ind. Bul. 213: 15, 16, 1911.

${ }^{5}$ Cavara, F.: Tubercolosi della vite. In, Intorno alla eziologia di alcune malattie di piante coltivate nota, Sta. Sperim. Agr. Italiane, 30 : 483-487, 1897. 
school of phytopathologists, the predispositionists. The Kühnian period had produced but one predispositionist of note, Ernst Hallier, whom I have already mentioned. The Millardetian period was but little more fortunate as to the number of disciples of this doctrine. On the other hand, the great predispositionists of this quartercentury were to far outshine in ability and success their predecessor of the earlier period. This doctrine so inauspiciously launched by Hallier was to find master champions in Sorauer of Germany and Ward of England.

Paul Carl Moritz Sorauer was born in 1839 and died January 9, 1916, at the age of seventy-seven. ${ }^{1}$ Of his early life and training I am unable to write. His biography is not as yet available to us. Like his German contemporaries of this period, he was already trained and had made some contributions to the science before the advent of the Millardetian period. The most noteworthy of his pre-Millardetian writings is the first edition of his handbook and his book on fruit diseases. (See footnotes 2 and 3, page 57.)

Sorauer, unlike Hallier, was largely free from the theories and dogmas incompatible with the scientific progress of his time. He was, nevertheless, an uncompromising predispositionist, and it is safe to assert that the modern interpretation of the doctrine of predisposition as set forth by Sorauer has much in it for thoughtful consideration by pathogenetists. That external factors, such as temperature, moisture, and nutrition, may gravely affect the constitution of the individual plant as

${ }^{1}$ A notice of Sorauer's death is to be found in Hedwigia, Beibl. $57: 151,1916$. 
regards its relation to the attacking pathogene is now held by many plant pathologists.

Sorauer's most noted contribution to phytopathology in the way of publications are the three editions of his text-book, Handbuch der Pflanzenkrankheiten. The first edition, a single volume written in 1874 while he was director of the Experiment Station for Plant Phys-

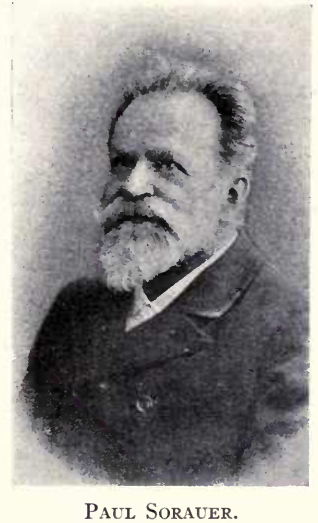

The great German predispositionist. (From a photograph, courtesy of Dr. Erwin F. Smith.)

iology at the Imperial Cider Institute of Proskau (Nature, $96: 600$ ), seems to have been his first contribution to the science (see footnote 2, page 57 ). The second edition appeared in two volumes in 1886 while he was still attached to the Pomological Institute at Proskau. The first volume, dealing with non-parasitic maladies, is twice the size of the second, dealing with the parasitic 
diseases. Thus is indicated, both by order and size, his predispositionist attitude. A third edition, completely revised, appeared in 1908-13. ${ }^{1}$ Sorauer is also well known as the founder and editor of the German phytopathologic journal, Zeitschrift für Pflanzenkrankheiten. He continued to write on phytopathologic subjects until his death, and was always much interested in international efforts to restrict the spread of plant pathogenes.

Harry Marshall Ward was undoubtedly the greatest of English phytopathologists. His work and influence, even more than that of Sorauer, has shaped our current ideas and researches on predisposition. Trained in the English University of Cambridge, he went abroad after taking his bachelor's degree, studying under Sachs and de Bary. From the latter he received his inclination toward the study of fungi, and from the former his physiologic point of view. His advent into the field of phytopathology came with his call in 1881, while still studying in Germany, to investigate the coffee disease then devastating the plantations of the island of Ceylon. This commission was executed with energy and brilliancy. His study of the pathogene, Hemeleia vastatrix, ${ }^{2}$ made

${ }^{1}$ The third edition appeared in three volumes. The first volume of 891 pages on non-parasitic diseases was written by Sorauer himself (issued in parts from 1905-09); the second volume of 550 pages on diseases caused by parasitic plants was prepared by G. Lindau (issued in parts from 1905-08); the third volume of about the same size on insect pests of plants was written by L. Reh (issued in parts from 1906-13).

${ }^{2}$ Ward, H. M.: On the morphology of Hemeleia vastatrix Berk. and $\mathrm{Br}$. (the fungus of the coffee disease of Ceylon), Quart. Jour. Microscop. Soc. n. S.; 22 : 1-11, 1882; also, Researches on the life history of Hemeleia vastatrix, the fungus of the "coffee-leaf disease," Jour. Linn. Soc., London, 19 : 299-335, 1882. 
him a predispositionist. After two years in Ceylon he returned to England, where after three years as Fellow at Owen College, Manchester, he was called to the chair of botany in the Forestry Department of the Royal Indian Engineering Collège at Coopers Hill. While here he naturally interested himself in forest botany.

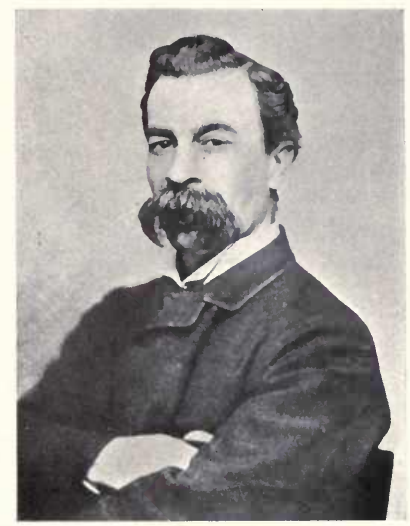

H. MARShali WARD.

The greatest English phytopathologist. (From a portrait in "Makers of British Botany.")

His chief pathologic contributions during this time were his book, Timber and some of its diseases ${ }^{1}$; Diseases of plants $^{2}$ (translated into Russian in 1891); and funda-

${ }^{1}$ Ward, H. M.: Timber and some of its diseases, pp. I-VIII + 1-295, 1909.

${ }^{2}$ Ward, H. M.: Diseases of plants, pp. 1-196, 1896. (Published by Society for Promoting Christian Knowledge, in the Romance of Science Series.) What appears to be a first edition of this appeared in 1889 under the same title and from the same publishers. 
mental studies on the life histories of several pathogenes, namely, Phytophthora infestans, Entyloma Ranunculi, Puccinia graminis, and the Botrytis sp. of lily. (See Lindau and Sydow, 1909, 2 :723-725.) In 1895 he was made professor of botany at the University of Cambridge, where he remained until his death in 1906 at the age of fifty-two. His years at Cambridge were full of activities along many lines of botany, both research and teaching, and were exceptionally fruitful. His chief pathologic papers during the last eleven years of his life were: Disease in plants, ${ }^{1}$ and his numerous classic studies from 1899 to 1905 on parasitism as exhibited in the rusts and other fungi. ${ }^{2}$ His studies in parasitism may be said to have laid the foundation for all later

${ }^{1}$ Ward, H. M.: Disease in plants, pp. I-XIV + 1-309, 1901.

${ }^{2}$ Ward, H. M.: On some relations between host and parasite in certain epidemic diseases of plants, Proc. Roy. Soc., London, 47 : 393-443, 1890. bibliography.)

Symbosis, Ann. Bot., 13 :549-562, 1889. (With extensive

- On the question of "predisposition" and "immunity" in plants, Proc. Cambridge Phil. Soc., 11 :307-328, 1902.

- On the relations between host and parasite in the Bromes and their brown rust, Puccinia dispersa (Eriks.), Ann. Bot., $16: 233-315$, 1902.

- Experiments on the effect of mineral starvation on the parasitism of the uredine fungus, Puccinia dispersa, on species of Bromus, Proc. Roy. Soc., London, 71 : 138-151, 1902.

- On pure cultures of a Uredine, Puccinia dispersa (Eriks.), Proc. Roy. Soc., London, 69 : 451-466, 1902.

- Further observations on the brown rust of the Bromes, Puccinia dispersa (Eriks.), and its adaptive parasitism, Ann. Mycol., $1: 132$ 151, 1903.

- On the histology of Uredo dispersa Eriks., and the "Mycoplasm" hypothesis, Phil. Trans. Roy. Soc., London, B : 196 : 29-46, 1904. $19: 1-54,1905$. 
investigations into the nature of susceptibility and immunity in plants. His last paper, Recent researches on the parasitism of fungi, appeared in the Annals of Botany in 1905.

Only the most noted pathologists of foreign countries of the Millardetian period have been mentioned. This period saw the rise and development of the science in

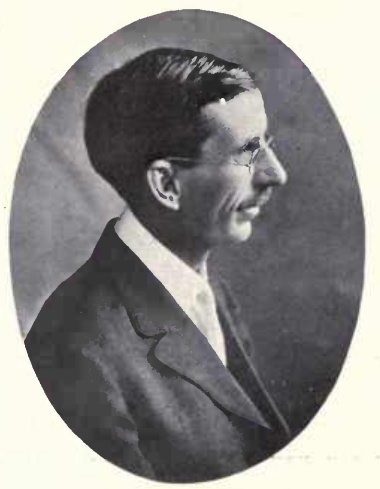

Beverly T. Galloway.

First chief of the U.S. Bureau of Plant Industry. (From a photograph.)

America. The men who were active in organizing and developing the work in the United States are almost without exception still living and contributing to its progress and growth. Future history may judge them as more of the following than of the Millardetian period. Certain of them, however, will doubtless stand forth as prominent figures of Millardetian times. I may be permitted to name those who in my judgment will be 
so known: F. L. Scribner, first federal phytopathologist; B. T. Galloway, first chief of the Bureau of Plant Industry in the United States Department of Agriculture; Erwin F. Smith, the dean of American phytopathologists and father of the science of bacterio-phytopathology ${ }^{1}$; J. C. Arthur, our greatest rust specialist ${ }^{2}$; T. J. Burrill, discoverer of bacterial phytopathogenesis; G. F. Atkinson, a noted American botanist, and author of several classics in phytopathology ${ }^{3}$; L. R. Jones, noted for his studies on the etiology and control of potato blights, ${ }^{4}$ his inves-

${ }^{1}$ A complete list of Smith's papers on bacterial diseases of plants would be too extensive for these pages. His pre-eminence in the field of bacterio-phytopathology has been fully established by his epochmaking studies on the crown gall, a plant cancer, and by his monographic work on bacterial diseases of plants, Bacteria in relation to plant diseases, three volumes of which have appeared, the first in 1905, the second in 1911, and the third in 1914.

${ }^{2}$ Besides many papers on various taxonomic phases of the rust problem, of which the most important to plant pathology are perhaps those detailing his cultural studies, Arthur is also the author of the rust section of the North American Flora.

${ }^{3}$ Among the more important may be cited: CEdema of the tomato, N. Y. (Cornell) Agr. Exp. Sta. Bul. 53 : 77-108, 1893; Leaf curl and plum pockets. Contribution to the knowledge of the prunicolous exoasceæ of the United States, N. Y. (Cornell) Agr. Exp. Sta. Bul. 73 : 319-355, 1894; Damping off, N. Y. (Cornell) Agr. Exp. Sta. Bul. 94 : 233-272, 1895; Studies of some shade tree and timber destroying fungi, N. Y. (Cornell) Agr. Exp. Sta. Bul. 193 : 199-235, 1901; Carnation diseases, Amer. Florist, $8: 720-728,1893$ (reprinted in the Amer. Florist, $24: 16-24,1905)$.

${ }^{4} \mathrm{His}$ investigations on the potato blight and its control conducted at the Vermont Station extend over a period of twenty years, beginning in 1890. This work is concisely reviewed by B. F. Lutman, Twenty years' spraying for potato diseases, Vermont Agr. Exp. Sta. Bul. 159. For other important contributions to this subject, see Jones, L. R., et al. Investigations of the potato fungus Phytophthora infestans, U. S. Dept. Agr. Bu. Pl. Ind. Bul. 245, especially the list of Jones' papers, pp. $89,90$. 
tigations on the etiology and nature of soft rots in vegetables, ${ }^{1}$ and for his work on wilt resistance in cabbage ${ }^{2}$; B. D. Halstead, for many years botanist of the New

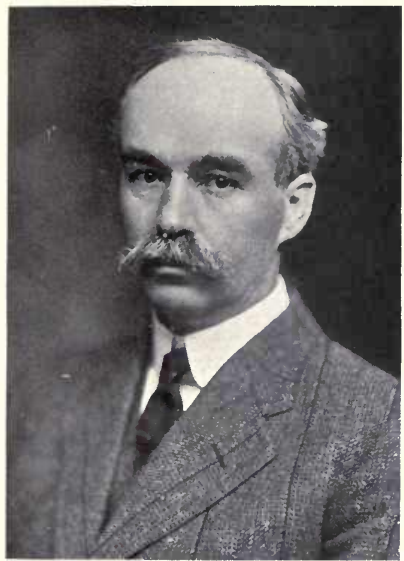

George F. Atkinson.

Noted American botanist and plant pathologist. (From a photograph.)

Jersey Experiment Station; H. L. Bolley, botanist of the North Dakota Experiment Station. He was the first

${ }^{1}$ Jones, L. R.: A soft rot of carrots and other vegetables, caused by Bacillus carotovorus, Jones, Vermont Agr. Exp. Sta. Rep. 13 : 299332,1901 . See also his paper on, Pectinase, the cytolytic enzyme produced by Bacillus carotovorus and certain other soft-rot organisms, New York (Geneva) Agr. Exp. Sta. Tech. Bul. $11: 2: 289-368,1909$.

${ }^{2}$ Jones, L. R.: The control of cabbage yellows through disease resistance, Wisconsin Agr. Exp. Sta. Research Bul. 38 : 1-70, 1915 (see especially list of papers by Jones, p. 69); also, Fourth progress report on Fusarium resistant cabbage. Abstract in Phytopath., $6: 102,1916$. 
to make practical use of the fungicidal properties of formaldehyd, ${ }^{1}$ and is widely known as the advocate of the seed and soil infestation theory for the explanation of the decreasing yields on western flax and wheat lands' F. C. Stewart, botanist of the New York (Geneva) Experiment Station, noted for the great variety of his studies on plant diseases ${ }^{3}$ and his ten-year experiments in potato spraying, ${ }^{4}$ and A. D. Selby, botanist of the Ohio Experiment Station. There are numerous others who in their earlier years contributed much to the advancement of the science, but who later passed into ad-

${ }^{1}$ Bolley, H. L.: New studies upon the smut of wheat, oats, and barley, with a résumé of treatment experiments for the last three years, North Dakota Agr. Exp. Sta. Bul. 27 :109-162, 1897. For excellent bibliography of early papers on formalin as a disinfectant, see Arthur, J. C., Formalin for prevention of potato scab, Indiana Agr. Exp. Sta. Bul. $65: 1-35,1897$.

${ }^{2}$ Bolley, H. L.: Wheat, North Dakota Agr. Exp. Sta. Bul. 107 : 1-94, 1913. See also Conservation of the purity of soils in cereal cropping, Science, n. s., 32 : 529-541, 1910; and, Plant diseases and crop rotation, The Northwestern Miller, 89 : 565-566, 585, 623, 624, 641, 642, 1912.

The main facts and the economic significance of soil infestation by phytopathogenes appears to have been first clearly set forth by Erwin F. Smith as a result of his studies on the Fusarium diseases of watermelons, cowpeas, cotton, tomatoes, sweet potatoes, and cabbage. The matter is admirably set forth by him in a paper under the title: The fungous infestation of agricultural soils in the United States, which appeared in The Scientific American, Supplement, No. 1246, pp. 19981, 19982, November 18, 1899.

${ }^{3}$ Stewart, F. C.: Botanical investigations. In, Twenty-fifth Anniversary Report 1882 to 1907, New York (Geneva) Agr. Exp. Sta. Ann. Rep. $26: 3: 119-162,1908$. Published also as reprint, pp. 1-44, 1908. This is a summary of botanical work at the station during these twenty-five years. For later papers by Stewart, see bulletins and reports of N. Y. (Geneva) Experiment Station since 1908.

${ }^{4}$ Stewart, F. C., et al: Potato spraying experiments, 1902-11, New York (Geneva) Agr. Exp. Sta. Bul. 349 : 99-139, 1912. 
ministration or other lines of botanical or agricultural work. Material for a fuller treatment of the lives and contributions of American phytopathologists is not yet

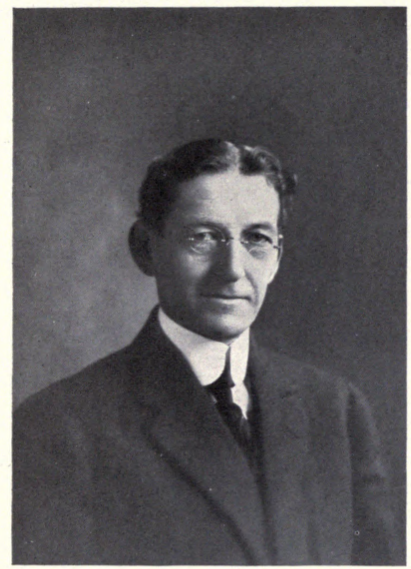

L. R. Jones.

A noted American investigator and teacher of plant pathology. (From a photograph, courtesy of Dr. W. A. Orton.)

assembled and put into form for presentation. May they all live to see such a survey of their work available as an inspiration to the rising generation of workers in plant pathology. 


\section{THE PRESENT ERA}

THE years from 1906 to 1912 mark, in my opinion, the beginning of a new era in the history of plant pathology. During these six years several events of special significance for the science occurred. These epoch-making events took place chiefly in America, indicating most definitely the transfer of the fate of phytopathologic science from the Old to the New World. Science, like empire, marches ever westward. Of these events, those most significant would seem to be: (a) The establishment of the first chairs of plant pathology in American Universities; (b) the discovery of the cause of crown gall and the beginning of Smith's classic investigations into the similarity of this disease to human cancer; $(c)$ the founding of the American Phytopathological Society and its journal, Phytopathology; $(d)$ the enactment of the United States Quarantine Act of 1912; $(e)$ introduction of sulfur as a substitute for copper in fungicides; $(f)$ the development, by selection and breeding, of crops resistant to pathogenes, and $(g)$ the outbreak of the destructive epiphytotic of chestnut blight which is fast wiping out the chestnut in eastern United States. These events constitute a combination as important in their bearing and as far reaching in their effects upon the science as those introducing the Millardetian period. Moreover, the decade from 1900 to 1910 saw the passing away of many of those figures whose personality and work strongly influenced our science during their time-Millardet in 1902, Hartig. 
in 1901, Frank in 1900, Ward in 1906, Delacroix in 1907, Rostrup in 1907. A few remain, veterans of the past, living inspirations for the future. Thus did the last decade of the Millardetian period presage the inaugural events of a new.

The Establishment of Chairs of Plant Pathology in Universities and Colleges of Agriculture.-Until very recent years plant pathology has been considered as simply a phase of botany or as applied mycology. A brief course in mycology masquerading under the name of plant pathology has in most cases sufficed to dispose of the subject. Even the so-called plant pathologists of the present day are in large part only mycologists with little of the true phytopathologic point of view. The first distinct department of plant pathology to be established, so far as I know, was the one at Cornell University in the autumn of 1907. Shortly thereafter (1909) the one at the University of Wisconsin, with Professor Jones at its head, was announced. Since that time several other state institutions have established teaching departments of plant pathology either independently or as a division of the botanical department. Minnesota, Illinois, and Iowa are examples of the latter.

Discovery of the Cause and Nature of Crown GallThis disease, so common to our cultivated fruit trees, had long been an object of investigation by pathologists in this country. The cause of the disease remained a mystery in spite of the evidence presented by Toumey ${ }^{1}$ to show that it was myxomycetous in nature. It remained for Dr. Erwin F. Smith, as perhaps the greatest single

${ }^{1}$ Toumey, J. W.: An inquiry into the cause and nature of crown gall, Arizona Agr. Exp. Sta. Bul. 33 : 1-64, 1900. 
contribution of his eminent career, to discover, in collaboration with his fellow-workers Townsend and Brown, the true cause of this interesting disease. Evidence of its bacterial nature was first set forth in Science ${ }^{1}$ in 1907. Following this there has appeared from the hand of Smith a series of most brilliant researches ${ }^{2}$ in which he has clearly shown the striking similarity in structure of this plant tumor to that of the cancer in man and animals.

The Establishment of the American Phytopathological Society.-The establishment of this society at the Baltimore meeting of the American Association for the Advancement of Science in $1909^{3}$ marks the beginning of another important development in American phytopathology, if not in that of the world. Within two years the society's membership exceeded 200, and at present totals approximately 350 . At the beginning of its third year, 1911, it undertook the publication of a journal, ${ }^{4}$ Phytopathology, designating it as the official organ of the

${ }^{1}$ Smith, Erwin F., and Townsend, C. O.: A plant tumor of bacterial origin, Science, n. s., $25: 671-673,1907$. (The pathogene named and briefly characterized.)

${ }^{2}$ For later papers on the same subject see: Crown gall of plants, Phytopath., 1 : 7-11, 1911; Crown gall of plants, its cause and remedy, U. S. Dept. Agr. Bu. Pl. Ind. Bul. 213, 1911; Crown gall and sarcoma, U. S. Dept. Agr. Bu. Pl. Ind. Circ. 85, 1911; The structure and development of crown gall, a plant cancer, U. S. Dept. Agr. Bu. Pl. Ind. Bul. 255, 1912; Mechanism of tumor growth in crown gall, Jour. Agr. Research, 8: 165-186, pls. 4-65, 1917; Mechanism of overgrowth in plants, Proc. Am. Phil. Society, $56: 437-444,1917$; Embryomas in plants (produced by bacterial inoculations). The Johns Hopkins Hospital Bull., 28 : 276-294, Sept., 1917. For list of other papers by this author see bibliography in last three papers.

${ }^{3}$ The American Phytopathological Society. (Report of first annual meeting.) Science, n. s., $31: 746-757,1910$.

${ }^{4}$ For data on establishment of the journal, see Science, n. s., 31 : 746, 1910; $33: 155,156,1911$; and Phytopath., $1: 38$ and 67, 1911. 
society. This journal, under the editorship of L. R. Jones, of the University of Wisconsin, and later Donald Reddick, of Cornell University, has been from the beginning a marked success. In it appears from year to year the first reports on new discoveries by American pathologists as well as contributions from foreign members. The journal has obtained a wide circulation abroad and has created a most favorable impression upon our foreign colleagues. This society and the journal it publishes has done more to stimulate and unify the phytopathologic work and workers of this country than any other one thing.

The United States Quarantine Act of 1912.-Congressman Simmons of New York introduced into the Sixtysecond Congress at its second session a bill to regulate the importation by the national government of nursery stock. This finally became a law in the form of the, National Quarantine Act of 1912. ${ }^{1}$ This was the first national enactment aimed at the exclusion, from this country, of insect pests and plant diseases. Other countries for years had various laws of this type, for the most part ineffective. The enactment of this measure, together with the establishment of a Federal Horticultural Board, marks a new period in the plant pathology not only of this country but of other countries as well. The exclusion of potatoes and certain nursery stock to protect

${ }^{1}$ The text of this act may be found in Circular $41: 7-11$, office of the secretary, U. S. Department of Agriculture, issued September 25, 1912, under the title: Rules and regulations for carrying out the plant quarantine act. Also in revised edition of Circular 41 of December 20, 1912; in Circular 44:12-15, May 26, 1913, text as amended March 4, 1913; and in unnumbered circulars issued by the Federal Horticultural Board, one of July 1, 1914. 
our growers from the introduction of dangerous pathogenes and pests aroused great antagonism abroad at first as well as some at home. It has, however, resulted in a marked improvement of foreign inspection and in extraordinary activity of our domestic inspection service.

The Introduction of Sulfur as a Substitute for Copper in Fungicides.-Lime-sulfur has long been known and used as an insecticide and to a very limited extent as a fungicide in cases where disinfection of dormant trees is desirable, as in the case of the peach leaf curl. ${ }^{1}$ Cordley of Oregon in 1906 discovered that much diluted solutions of lime-sulfur might be used with safety and efficiency as a summer spray for apple scab. ${ }^{2}$ Scott in 1907 devised and tested out the so-called self-boiled lime-sulfur mixture. ${ }^{3}$ He showed that it could be used successfully in the control of the scab and brown rot of peaches, without at the same time causing injury to the tender foliage of the peach, such as results from the use of copper sprays or of solutions of calcium sulfids. These discoveries were soon

${ }^{1}$ The early history of the use of sulfur solutions for the control of peach leaf curl is set forth in detail by N. B. Pierce in, Peach leaf curl, its nature and treatment, U. S. Dept. Agr. Div. Veg. Path. and Phys. Bul. 20:46-66, 1900. Long before this, however, dilute solutions of lime-sulfur concentrate had been recommended as a spray for grapes to control the powdery mildew. (Regel, E. Die Schmarotzergewächse und die mit denselben in Verbindungstehenden Pflanzenkrankheiten, pp. 111, 112, 1854.)

${ }^{2}$ See Cordley, A. B.: Lime-sulfur spray as a preventive of apple scab, Rural New Yorker, March 1, 1908 : 202; Oregon Agriculturist, March 1, 1908 : 178, or Better Fruit, September, $1908: 26$; also, Whetzel, H. H., Summer use of concentrated lime-sulfur, N. Y. State Fruit Growers' Assoc. Ann. Rep., $9: 31-33,1910$.

${ }^{3}$ Scott, W. M.: Self-boiled lime-sulfur mixture as a promising fungicide, U. S. Dept. Agr. Bu. Pl. Ind. Circ. 1 : 1-18, 1908; also, Circ. $27: 1-17,1909$. 
heralded throughout the United States and Canada, receiving a most cordial reception from growers and some pathologists, as promising substitutes for bordeaux mixture, so frequently injurious to fruit and foliage. Within half a decade lime-sulfur almost completely replaced bordeaux mixture for apples and some other crops. It has not proved a satisfactory substitute, however, in the case of grapes and potatoes. ${ }^{1}$ Studies soon indicated that it is the finely divided sulfur on the foliage which is the effective agent. Following this idea, dusting with finely ground sulfur has been carefully investigated by Blodgett, ${ }^{2}$ Reddick, ${ }^{3}$ and Stewart ${ }^{4}$ of Cornell, who have conclusively shown that dry sulfur may safely and profitably replace the liquid sprays for the control of some of our most common and destructive diseases. Our day is to see sulfur the chief fungicide as against the copper of the Millardetian period.

Development of Disease-resistant Crops.-The extraordinary progress which is now being made in this direction is the logical outgrowth of the pioneer labors of an

${ }^{1}$ For the results on grapes, see Reddick, D., et al: Spraying for black rot of the grape in a dry season, New York (Cornell) Agr. Exp. Sta. Bul. 296 : 586, 587, 1911; and for those on potatoes, see Stewart, F. C., and French, G. T.: Lime-sulfur vs. Bordeaux mixture as a spray for potatoes. I. New York (Geneva) Agr. Exp. Sta. Bul. 347, 1911; Munn, M. T., II. Bul. 352, 1912; III. Bul. 397, 1915; IV. Bul. 421, 1916.

${ }^{2}$ Blodgett, F. M.: Hop mildew, New York (Cornell) Agr. Exp. Sta. Bul. 328, 1913; and, Further studies on the spread and control of hop mildew, New York (Geneva) Agr. Exp. Sta. Bul. 395, 1915.

${ }^{3}$ Reddick, D., and Crosby, C. R.: Dusting and spraying experiments with apples, New York (Cornell) Agr. Exp. Sta. Bul. 369, 1916.

${ }^{4}$ Stewart, V. B.: Dusting and spraying nursery stock, New York (Cornell) Agr. Exp. Sta. Bul. 385, 1917. 
eminent American pathologist, W. A. Orton. ${ }^{1}$ During the decade from 1899 to 1909 he obtained by selection and breeding strains of cotton, melons, and cowpeas resistant to Fusarium wilt fungi. His results at once stimulated wide-spread search for disease-resistant strains in many other of our cultivated crops.

The Epiphytotic of Chestnut Blight.-This, the most devastating disease of modern times, was first observed in New York City abut 1904. At this time it was found to be thoroughly established on Long Island and the immediate vicinity of New York City. It then spread rapidly in all directions from this center, and by 1914 had extended throughout the southern New England States, southern Vermont, New Hampshire, the Hudson Valley and the eastern half of Pennsylvania, as well as south through New Jersey, Delaware, eastern West Virginia, Maryland, and northern Virginia. Its ravages aroused general alarm among laymen as well as pathologists. Large sums of money were appropriated both by the Federal Government and by several of the states for the purposes of investigation and control. While all efforts to stay its progress have failed, it has served to impress upon the people of the United States the danger from such destructive plant diseases, and has resulted in a

${ }^{1}$ The following papers by Orton should be consulted: The wilt disease of cotton and its control, U. S. Dept. Agr. Div. Veg. Phys. and Path. Bul. 27 : 1-15, 1900; Some diseases of the cowpea, U. S. Dept. Agr. Bu. Pl. Ind. Bul. 17 : 1-36, 1902; On the breeding of disease-resistant varieties, Hort. Soc. New York, Mem., 1:41-52, 1902; Plant breeding as a factor in controlling plant diseases, Amer. Breeders' Assoc., 1 : 69-72, 1905; On the theory and practice of breeding disease-resistant plants, Amer. Breeders' Assoc., 3 : 144-156, 1908; The development of diseaseresistant varieties of plants, IV Conférence Internat. de génétique, Paris, 1911, Comp. Rend. et Rapports, pp. 247-261, 1913. 
keen appreciation of the necessity for more intelligent legislation and efforts in meeting similar danger to other crops. It has been, like the potato blight epidemics of the early forties, a potent factor in giving to the lay mind a proper appreciation of the importance of phytopathology in the economics of crop production. The history of this epiphytotic has been accurately outlined by Anderson and Rankin. ${ }^{1}$

I have intentionally refrained from an attempt to analyze in more detail the trend of phytopathologic thought and development in the present era. We are too near to it, being in the midst of it, to justly weigh the relative importance of passing events and current contributions. Those who are making the history of our science are our friends and our colleagues. Their scientific faults and virtues are likely to loom up quite out of proportion to their real significance in the evolution of plant pathology. My verdict on the makers of the Millardetian period is doubtless more or less invalidated for the same reason. Some of them still stand forth in the flesh to challenge or accuse me; those whom I have named and those whom I have refrained from naming. To each his consolation; to the former, that he stands among the founders of the science in this country; to the latter, that somewhere in the annals of plant pathology future historians must give him a place.

${ }^{1}$ Anderson, P. J., and Rankin, W. H.: Endothia canker of Chestnut, New York (Cornell) Agr. Exp. Sta. Bul. 347 : 538-545, 1914. 


\section{BIBLIOGRAPHY}

\section{HISTORIC ${ }^{1}$}

Arthur, J. C.: History and scope of plant pathology, Cong. Arts and Science, St. Louis, 5 : 149-164, 1906.

de Bary, Anton: Untersuchungen über die Brandpilze und die durch sie verursachten Krankheiten der Pflanzen, mit Rücksicht auf das Getreide und andere Nutzpflanzen, pp. I-VIII + 1-144, Berlin, 1853.

Buller, A. H. R.: The fungus lore of the Greeks and Romans, British Myc. Soc. Trans., $5: 30-33,1915$.

Dugger, B. M.: Fungous diseases of plants, pp. 2-4, 1909.

Eriksson, J., and Henning, E.: Die Getreideroste, ihre Geschichte und Natur, sowie Massregeln gegen dieselben, pp. 7-24, 1896.

Farlow, W. G.: The change from the old to the new botany in the United States, Science, n. s., 37 : 79-86, 1913.

Galloway, B. T.: Progress in the treatment of plant diseases in the United States, U. S. Dept. Agr. Year Book for 1899 : 191-200, 1900.

Twenty years' progress in plant pathology, Proc. Soc. Prom. Agr. Sci. Ann. Meeting $21: 90-102,1900$.

Greene, E. L.: Landmarks of botanical history. A study of certain epochs in the development of the science of botany. Part 1.Prior to 1562 A. D. Smithsonian Miscell. Coll., 54 : 1 : 1-329, 1909.

Green, J. Reynolds: A history of botany, 1860-1900, being a continuation of Sachs' History of Botany, 1530-1860, pp. 1-543, Oxford, 1909.

- A history of botany in the United Kingdom, from the earliest times to the end of the 19th Century, pp. I-XII + 1-648, London and Toronto, 1914. (Published after the author's death.)

Hartig, R.: Text-book of the diseases of trees. (Transl. by Wm. Sommerville), pp. X-XVII and 1-4, 1894.

Hollrung, M.: Die Mittel zur Bekämpfung der Pflanzenkrankheiten, pp. $1-3,1914$.

Jensen, C. N.: Résumé of publications on plant pathology, Thesis, Cornell University, pp. 1-69, 1909.

Jones, L. R.: Problems and progress in plant pathology, Amer. Jour. Bot., 1 : 97-111, 1914.

${ }^{1}$ Only those pages containing data of historic interest are given for these references. 
Klebahn, H.: Die wirtswechselnden Rostpilze. Versuch einer Gesamtdarstellung ihrer biologischen Verhältnisse, pp. 5-12, 1904.

Lind, J.: Danish fungi as represented in the herbarium of E. Rostrup, pp. 1-9, 19-25, 1913.

—_ Berberisbusken og Berberisloven. Tids. Planteavl., 22 : 729$780,1915$.

Lodeman, E. G.: The spraying of plants, pp. 1-114, 181-207, 1896. (See same pages in the 1906 edition.)

McAlpine, D.: The smuts of Australia, pp. 4-7, 1910.

Meyer, E. H. F.: Geschichte der Botanik, $1: \mathrm{I}-\mathrm{X}+1-430$, 1854;

$2: I-X+1-430,1855 ; 3: I-X V I+1-455,1856 ; 4:$ I-VIII + $1-451,1857$

Potter, M. C.: Bacteria in their relation to plant pathology, British Myc. Soc. Trans., $3: 150-168$, 1910. (Gives extensive bibliography.)

Ré, Count Philippo: Essay theoretical and practical on the diseases of plants. (Translated from the Italian.) Gard. Chron., $1849: 211$, $228-229,1849$. The original was published in 1807. (See footnote 3, page 32.) This translation is from the second edition, 1817. Ritzema-Bos, J.: Instituut voor phytopathologie, verbonden aan de Rijks Hoogere Land-,Tuin-, en Boschbouwschool te Wageningen. Tijds. over Plantenz., 12:17-27, 1906. He here describes the establishment of the first royal phytopathological institute in Holland.

Het phytopathologisch laboratorium Wille Commelin Scholten van 1895 tot 1906. Tijds. over Plantenz., $12: 28-58,1906$. He reviews the history of the foundation and development of this privately endowed phytopathological institute in Amsterdam.

Rostrup, E.: Plantepathologi, pp. 1-9, 1902.

Sachs, Julius: Geschichte der Botanik vom 16 Jahrhundert bis 1860 , pp. I-XII + 1-612, 1875; also the English translation by Garnsey and Balfour, pp. I-XV + 1-568, 1900.

Savastano, L.: La patologia vegetale die Greci, Latini ed Arabi, Memoria, pp. 1-75, Portici, 1890-91.

Selby, A. D.: The future of vegetable pathology, Science, n. s., 15 : 736$740,1902$.

Smith, Annie L.: Microfungi: a historical sketch, British Myc. Soc. Trans., 3 : 18-25, 1908.

Smith, Erwin F.: Plant pathology: a retrospect and prospect, Science, n. s., $15: 601-612,1902$.

Bacteria in relation to plant diseases, $2: 7-22,1911$. He gives here an historical review of the rise and development of bacteriophytopathology. 
Sorauer, P.: Handbuch der Pflanzenkrankheiten, $1: 37-68$, 1909; also the translation by Frances Dorrance under the title: Manual of plant diseases, $1: 41-71,1914$.

Stevens, F. L.: The science of plant pathology, Jour. Elisha Mitchell Sci. Soc., 20 : 61-75, 1904. (Reprinted from Popular Science Monthly, September, 1905.)

Stevens, F. L., and Hall, J. G.: Diseases of economic plants, pp. 3-12, 1910.

Ward, H. Marshall: Disease in plants, pp. 85-90, 1901.

Recent researches on the parasitism of fungi, Ann. Bot., 19 : 1-54, 1905.

Westerdijk, Johanna: De nieuwe wegen van het phytopathologisch onderzoek. Rede uitgesproken bij het aanvaarden van het ambt van buitengewoon hoogleeraar aan de Universiteit te Utrecht, op Zaterdag, 10 February, pp. 1-38, Amsterdam, 1917.

\section{BIBLIOGRAPHIC}

Boehmer, George Rudolph: Bibliotheca scriptorum historiae naturalis oeconomiae aliarum ac scientiarum ad illam pertinentium realis systematica. Pars III, Phytologi $1: 1-808,1787$. On pages 522 546 will be found an extensive list of references on diseases of plants. See pages $459-470$ for references on frost and weather injury; and pages 514-522 for references on teratology.

Jackson, B. D.: Guide to the literature of botany, pp. 102-105, 1881.

Lindau, G., and Sydow, P.: Thesaurus litteraturae mycologicae et lichenologicae, 1-4, 1908-15.

Pritzel, G. A.: Valetudo et morbi plantarum. In, Thesaurus literaturae botanicae, pp. 526, 527, 1872; also 2 d ed., pp. 526, 527, 1877.

Rehder, A.: The Bradley Bibliography. A guide to the literature of the woody plants of the world, published before the beginning of the twentieth century, $1: 1: 206-216,1911 ; 3$ : 178-186, 193-198, 1915; $4: 65,66,188-196,210-212,1914$.

\section{BIOGRAPHIC}

\section{GeNeraL}

Michaud, J. F. and L. G.: Biographie universelle, ancienne et moderne, $1-52,1811-62$.

Saccardo, P. A.: La botanica in Italia. [Reprinted from] Mem. Reale Inst. Veneto Scienze, Lettere ed Arti, $25: 1-236,1895$; part 2: $\mathrm{I}-\mathrm{XV}+1-172,1901$. The latter is an addendum. These give brief biographical notes on Italian botanists both living and dead. 
Wittrock, V. B.: Catalogus illustratus iconotheca botanicae horti Bergiani Stockholmiensis natulis biographicis adjectis. Acta Horti Bergiani, $3: 2: 1-198$, tab. 1-37, 1903; $3: 3:$ I-XCIII + 1-245, tab. 1-150, 1905. (Half-tones and biographic sketches of ancient and modern botanists.)

\section{INDIVIDUAL}

\section{Adanson, Michel}

Cuvier, Baron [G.]: Biographical memoir of Michel Adanson. Read to the institute of France, Edinburgh New Phil. Jour. n. s., 3 : 1-21, 1827. This is a translation from the French, Eloge historique de Michel Adanson, Mem. classe Sci. Mat. e. Phys. Inst. National France [Acad. Sci.], $1806: 2: 159-188,1907$.

Anonymous: Nekrolog. Michel Adanson, Mitglied der ehemaligen Akademie der Wissenschaften und des National-Instituts, u. s. w., geboren 1727, gestorben 1806. Intelligenzblatt Allgem. Litteratur Zeit., 1806 : 1257-1260, 1806.

\section{de Bary, Heinrich Anton}

Balfour, B.: Professor Heinrich Anton de Bary, Trans. Bot. Soc. Edinburgh, $17: 350-354,1889$. (Chiefly a list of his publications.) Farlow, W. G.: Professor Anton de Bary, Garden and Forest, 1 : 15, 16, 1888.

Murray, G.: Heinrich Anton de Bary, Jour. Bot., 26 : 65-67, 1888. See also Ann. Bot., 2 :393-397, 1889. (Short biographical sketch with list of publications.)

Prantl, K.: Anton de Bary, Hedwigia, 27 : 77-86, 1888. (Portrait and bibliography.)

Rees, M.: Anton de Bary, Ber. Deut. Bot. Ges., 6 : VIII-XXVI, 1888. (Portrait and list of publications.)

Smith, Erwin F.: Anton de Bary, Phytopath., $1: 1,2,1911$. (Portrait.) Wilhelm, K.: Nekrologe. Anton de Bary, Ein Nachruf, Bot. Centralbl., 34 : 93, 94, 156-158, 191, 192, 221-224, 252-256, 1888. (List of publications.)

\section{Berkeley, Miles Joseph}

Baker, J. G.: The Rev. M. J. Berkeley, Nature, $40: 371,372,1889$.

Cooke, M. C.: The Rev. M. J. Berkeley, Grevillea, 18 : 17-19, 1889; for portrait see Grevillea, 1 : frontispiece, 1872.

Druce, G. C., and Taylor, J.: Northamptonshire obituaries: The Rev. Miles Joseph Berkeley, M. A., F. R. S., F. L. S., Northamptonshire Notes and Queries, $4: 25-37,221-224,1892$. (Portrait and complete list of publications.) 
Farlow, W. G.: Miles Joseph Berkeley, Garden and Forest, 2 : 410, 411, 1889.

Green, J. Reynolds: Berkeley. In, A history of botany in the United Kingdom from the earliest times to the end of the 19th Century, pp. 445-447, 1914.

Hooker, J. D.: The Rev. Miles Joseph Berkeley, Proc. Roy. Soc., London, 47 : IX-XII, 1890.

Lloyd, C. G.: Rev. M. J. Berkeley. In, Synopsis of the stipitate Stereums, p. 14, 1913. (Portrait with note.)

[Morrens, E.]: Prologue en l'honneur de Rev. M. J. Berkeley, membre de la Societé Linneé de Londres, La Belgique Hort. Ann. Hort. Belge, et Etrangere, 22 : 5-9, 1872. (Portrait.)

Massee, Geo.: Miles Joseph Berkeley, 1803-89. In, Makers of British Botany by Oliver, pp. 225-232, 1913. (Portrait.)

[Murray, Geo., and Editors]: The Rev. M. J. Berkeley, M. A., F. R. S., Jour. Bot., 27 : 305-308, 1889; also, Miles Joseph Berkeley, Ann. Bot., $3: 451-456,1890$. (Consist chiefly in a long list of his published papers.)

Thiselton-Dyer, W. T.: Miles Joseph Berkeley. Born 1803. Died 1889. Ann. Bot., 11 : IX-XI, 1897. (Portrait.)

Anonymous: Obituary. Miles Joseph Berkeley, Gard. Chron., $3: 6: 141,142$, 1889. (Portrait, p. 135.)

\section{Berlese, Augusto Napoleone}

Berlese, A.: Augusto Napoleone Berlese. 21 Ottobre, 1864-26 Gennaio, 1903, Riv. Pat. Veg., $10: 347-394,1904$. (Portrait and copies of obituary notices published in other journals, with a complete list of titles of his published papers.)

Cavara, Fr.: A. N. Berlese (Nekrologe), Ann. Myc., 1 : 178-180, 1903.

Saccardo, P. A.: Augusto Napoleone Berlese. Cenno necrologico, Malphigia, $17: 117-126,1903$.

\section{Burrill, Thomas Jonathan}

Davenport, E.: Dr. Thomas Jonathan Burrill. Memorial address, Trans. Ill. Hort. Soc., n. s., $50: 67-97,1917$. (Portrait and list of publications.)

Forbes, S. A.: Thomas Jonathan Burrill. Alumni Quarterly and Fortnightly Notes, University of Illinois, July 15, 1916.

Smith, Erwin F.: In memoriam of Thomas J. Burrill, Jour. Bact., 1 : 269-271, 1916. (Portrait.)

Trelease, Wm.: Thomas Jonathan Burrill, April 25, 1839-April 14, 1916, Bot. Gaz., 42 : 153-155, 1916. 


\section{Delacroix, Georges}

Prillieux, E. E.: Notice sur la vie et les travaux de Georges Delacroix, Bul. Soc. Myc. France, 24 : 48-67, 1908. (Portrait.)

\section{Fabricius, Johann Christian}

Lind, J.: Danish fungi as represented in the herbarium of E. Rostrup, pp. 19, 20, 1913. (Portrait.)

Latreille, M.: Notice biographique. Sur Jean Chretien Fabricius, conseiller d'etat du roi de Dannemarck, professeur d'histoire naturelle et d'economie rural à Kiell, et membre d'un grand nombre d'academies, Ann. Mus. Hist. Nat., 11 : 393-404, 1808.

\section{Forsyth, William}

Anonymous: Early writers on English gardening. William Forsyth, Jour. Hort. Cottage Gardner and Country Gentleman (old ser. 56), n. s., $31: 147,1876 . \quad$ (Portrait.)

Anonymous: Centenary of the horticultural society. The Founders: William Forsyth, Gard. Chron., 3 : $35: 147$, 148, 1904.

\section{Frank, Albert Bernhard}

Krüger, F.: Albert Bernhard Frank, Ber. Deut. Bot. Ges., 19 : (10)(36), 1902. (Complete bibliography of his works.)

Lopriore, G.: A. B. Frank, Malphigia, $14: 387-410$, 1900. (Portrait and list of his publications.)

Nobbe, F.: Albert Bernhard Frank, Landw. Vers. Stat., 55 : 159, 160, 1901.

Anonymous: Biographische Mittheilungen. Albert Bernhard Frank, Leopoldina, $36: 170,171,1900$.

\section{Hales, Stephen}

Darwin, F.: Stephen Hales, 1677-1761. In, Makers of British Botany by Oliver, pp. 65-83, 1913. (Portrait.)

Green, J. Reynolds: Stephen Hales. In, The history of botany in the United Kingdom from the earliest times to the end of the 19th Century, pp. 198-206, 1914.

Anonymous: British botanists: Stephen Hales, Gard. Chron., 3 : 49 : 88, 89, 1911. (Portrait.)

\section{Hallier, Ernst}

Anonymous: Hallier, Ernst: Brockhaus' Konver.-Lexik., 8 : 684, 4th ed., 1894.

Anonymous: Biographische Mittheilungen. Ernst Hallier, Leopoldina, $41: 38,1905$.

For a notice of his death, see Bot. Centralbl., $98: 32,1905$.

\section{Hartig, Heinrich Julius Adolph Robert}

Cieslar, R.: Robert Hartig, Centralbl. Gesamte Forstw., 28: 37-46, 1902. (Portrait.) 
Meinecke, E. P.: Robert Hartig. Ein Nachruf. Allegm. Forst.-u.Jagd. Zeit., 78 : 129-131, 1902; also, Robert Hartig (1839-1901). Phytopath., $5: 1-3,1915$. (Portrait.)

Tubeuf, Carl von: R. Hartig, Nekrolog. Ber. Deut. Bot. Ges., 20 : (8)(28), 1903.

Anonymous: Dr. Robert Hartig, Proc. Linn. Soc., London., 114 : 3537, 1902.

Anonymous: Biographische Mittheilungen. Robert Hartig, M. N. A., Leopoldina, 37 : 94-95 (also 90), 1901.

\section{Ibn-al-Awam (Yah'yā Ibn Muh'ammad or Abū Zakariyā)}

Meyer, E. H. F.: Ibu-al-Awam. In, Geschichte der Bontanik, $3: 260-266,1856$.

\section{Jensen, Jens Ludvig}

Ravn, F. Kolpin: Jens Ludvig Jensen (1836-1904), Phytopath., $7: 1-4,1917$. (Portrait.)

Lind, J: Jensen, Jens Ludwig. In, Danish Fungi as represented in the herbarium of E. Rostrup, p. 31, 1913. (Portrait.)

Anonymous: Personalia Direkter Jens Ludwig Jensen, födt, 1836. Aarsb. Kong. Dansk. Landh.-Skab., 1904-05 : 288, 1905. (Portrait.)

\section{Kühn, Julius Gotthelf}

Holdefleiss, P.: Julius Kühn, Nachruf. Naturw. Rundschau, 25 : 297299, 1910.

Wohltmann, F., and Holdefleiss, P.: Julius Kühn, sein Leben und Wirken. Festschrift zum 80 Geburtstag am 23. Oktober, 1905. pp. 1-56, Berlin, 1905. (Portrait.)

Anonymous: Die Julius Kühn-Ehrung am 15. Juni ds. Js., Deut. Landw. Presse, $28: 444,445,1901$. (With photographs of the gathering.)

Anonymous: Zum 70. Geburtstag Julius Kühns. Aus dem Lebensgang Julius Kühns. Deut. Landw. Presse, 22 : 767, 1895. (With excellent full-page portrait.)

McAlpine, Daniel

Anonymous: A prominent fruit expert: Professor D. McAlpine. In, The Fruit World of Australia, August 1, 1915, p. 255.

\section{Meyen, Franz Julius Ferdinand}

Ratzeburg, J. T. C.: Meyen's Lebenslauf, Verh. Kais. Leopol.-Carol. Akad. Naturforscher, Erstes Suppl., 19 : XIII-XXXII, 1843.

\section{Millardet, Pierre Marie Alexis}

Bornet, E.: Necrologie Millardet (Pierre-Marie-Alexis), Bul. Soc. Bot. France, $49: 318,1902$.

Galloway, B. T.: Pierre-Marie-Alexis Millardet (1838-1902), Phytopath., $4: 1-4,1914$. (Portrait.) 
Gayon, U., and Sauvageau, C.: Notice sur la vie et les travaux de A. Millardet (1838-1902), Mem. Soc. Sci. Phys. et Nat. Bordeaux, $6: 3$ : IX-XLVII, 1903. (P ortrait and list of publications.)

Magnus, P.: Millardet, Ber. Deut. Bot. Ges., 22 : (10)-(14), 1905.

\section{$\phi_{\text {rsted, Anders Sandöe }}$}

Brown, R.: Life and labors of Professor $\Phi_{\text {rsted, Trans. Bot. Soc., }}$ Edinburgh, $11: 426-435,1873$.

Lind, J.: Anders Sandöe $\Phi_{\text {rsted. }}$ In, Danish fungi as represented in the herbarium of E. Rostrup, pp. 17, 18, 1913. (Portrait.)

\section{Pliny the Second}

Greene, E. L.: Caius Plinius Secundus (A. D. 23-79). In, Landmarks of Botanical History, Smithsonian Miscell. Coll., 54 : 1 : 155-159, 1909.

\section{Prillieux, Edouard Ernest}

Berthault, P.: Mort de M. Edouard Prillieux, Jour. Agr.'Prat,, 79 : 583, 584, 1915; also, *Edouard Prillieux, Rev. Gén. Bot., 28 : 193-203, 1916.

Bois, D., and Grignan, G. T.: Necrologie-M. Ed. Prillieux. Rev. Hort., 87 : 580, 1915.

Pinoy, E.: Ed. Prillieux, Bul. Soc. Myc., France, 32 : 7-16, 1916. (Portrait and bibliography of his works.)

Notices of his death are to be found in: Revue Gen. Bot., $27: 352$, 1915; Gard. Chron., 3 : 58 : 282, 1915; and Jour. Soc. Nat. Hort., France, $16: 152,1915$.

\section{Ré, Filippo}

Saccardo, P. A.: In, La Botanica in Italia (Mem. Reale Inst. Veneto Sci., Lett. e Arti, $25: 135,1895)$, gives the following facts: Born March 20, 1763; died March 25, 1817. Professor of agriculture in the University of Bologna; afterward Professor of agriculture and botany at Modena. Then follows references to biographies from Italian sources. (See also part II of the above, p. 89, 1901.)

\section{Rostrup, Fredrick George Emil}

Lind, J.: [Biographical data]. In, Danish fungi as represented in the herbarium of E. Rostrup, pp. 1-9, 1913.

Rayn, F. K申lpin: E. Rostrup (Nekrolog.), Ber. Deut. Bot. Ges., 26a : (47)-(55), 1909.

Rosenvinge, L. Kolderup: Emil Rostrup. En Levnedsskildring, Bot. Tidssk., 28 : 185-198, 1908. (Portrait.)

\section{Sorauer, Paul Carl Moritz}

[Notice of his death.] Hedwigia, 57 : (150), Beibl. für December, 1915, 1916; a fuller note is to be found in Nature, $96: 600,1916$. 


\section{Theophrastus of Eresus}

Greene, E. L.: Theophrastus of Eresus, B. C. 370-286 (or 262). In, Landmarks of Botanical History, Smithsonian Miscell. Coll., 54 : 1 : 52-142, 1909.

Hort, Sir Arthur: Theophrastus' life and works. In, Theophrastus, Enquiry into Plants, 1 : XVII-XXIII, 1916.

\section{Tournefort, Joseph Pitton de}

Lauthier, H. M.: The life of M. Tournefort; in a letter to M. Begon, Intendant of the Marine at Rochefort, etc. In, Tournefort's, A voyage into the Levant, 1 : V-XXXVI, London, 1741. Following this in the same volume is, The elogium of M. Tournefort, By M. Fontenelle, perpetual secretary of the Royal Academy and one of the Forty of the French Academy, pp. XXXVIII-XLIX.

Lefébure, E. F. H.: Eloge de Tournefort, Mem. Soc. Linn., Paris, 1 : 639-648, 1822 .

Anonymous: Eloge de M. Tournefort, Hist. Acad. Roy. Sci. annee 1708 : 143-154, 1730.

\section{Unger, Franz Joseph Andreas Nicholas}

Leitgeb, H.: Zur Errinnerung an Franz Unger, Bot. Zeit., 28 : 241-257. Verzeichness der gedruchten Schriften F. Unger's, pp. 257-264, 1870; also, Franz Unger, Mitth. Naturw. Vereins f. Steiermark, 2 : 270286, 1870. (Portrait in front of volume.)

Neilreich, A.: Gallerie österreicher Botaniker. Franz Unger, Oester. Bot. Zeitsch., 14 : 1-9, 1864. (Portrait.)

* Reyer, Alex.: Leben und Wirken des Naturhistorikers, Dr. Franz Unger, Professor der Pflanzen-Anatomie und Physiologie, p. 4 unnumbered + 1-100, Gratz, 1871. An abstract of this is to be found in Flora, 54 : 361-366, 1871.

Anonymous: Dr. Franz Unger. Anthropol. Rev. (Jour. Anthropol., October, 1870), $8: 227-232,1870$. (Portrait.)

Anonymous: Obituary of Dr. Franz Unger, Jour. Bot., 8 : 192-203, 1870. (Portrait and list of publications.)

\section{Ward, Harry Marshall}

Balfour, I. B.: Harry Marshall Ward, Trans. and Proc. Bot. Soc., Edinburgh, 23 : 218-232, 1908. (Chronology and bibliography.)

Boodle, L. A.: H. Marshall Ward, Bul. Misc. Information Kew, $1906: 281,282,1906$.

Bower, F. O.: Harry Marshall Ward, F. R. S., Jour. Bot., 44 : 422-425, 1906.

Freeman, E. M.: Harry Marshall Ward (1854-1906), Phytopath., $3: 1,2,1913$. (Portrait.) 
Jackson, B. D.: Harry Marshall Ward, Proc. Linn. Soc., London, $119: 54-57,1907$.

Johnson, T.: H. Marshall Ward, Ber. Deut. Bot. Ges., 26a : (10)-(12), 1909.

Thiselton-Dyer, W. T.: Harry Marshall Ward, 1854-1906, Proc. Roy. Soc., London, B : 83 : I-XIV,.1911; see also New Phytol., 6 :1-9, 1907; and Makers of British Botany by Oliver, pp. 262-279, 1913. (Portrait.)

Vines, S. H.: Professor H. Marshall Ward, Nature, 74 : 493-495, 1906; see also, Ann. Bot., 21 : IX-XIII, 1907; and, Bot. Centralbl., 102 : 367, 368, 1906.

Anonymous: Two leaders in science, Gard. Chron., 3 : $40: 164,1906$. Weigmann, Arend Joachim Friedrich

No published biography of Wiegmann has been found. The following facts have been gathered from several sources, but chiefly from a seminary paper presented by Charles Chupp before the department of plant pathology of Cornell University in 1913. A copy of this paper is to be found in the library of Cornell University. Wiegmann was born 1771; died 1853 in Braunschweig. He was examined for assistant chemist by the Imperial College in Braunschweig in 1795, and appointed associate pharmacist to the chief apothecary there. From 1821 on he lived as a private druggist in Braunschweig, but having taken his medical degree in 1827 , he was appointed to a professorship there. He began his studies in plant pathology in 1798, his first contribution in this field being apparently his, Versuch einer Krankheitslehre der Gewächse, which appeared in the first three volumes of Sprengel's, Land- und Forstwissenschaftliche Zeitschrift, which formed the basis of his text-book issued in 1839 (see footnote 1, p. 37). He also interested himself in, and wrote papers on, plant hybridization; the nature and origin of peat; and the inorganic constituents of plants. The following references give some few facts regarding him: Ascheron, P., and Graebner, P., Synopsis der Mittel-Europäischen Flora, $6: 2: 1086$, footnote, 1910; Flora, $36: 288,1853$; Bot. Zeit. $11: 279,280,1853$. A fine lithograph portrait is to be found in the Van Kaathoven collection of medical men in the library of the Surgeon General's office, Washington, D. C.

\section{Woronin, Michael Stepanovitch}

Famintzin, A. S.: M. S. Woronin (Nekrolog), Trav. Imp. Soc. Nat., St. Petersburg, $34:$ 210-222, 1903. (Portrait.) In Russian.

Nawaschin, S.: Michael Woronin, Ber. Deut. Bot. Ges., 21 :(35)-(47), 1903.

Smith, Erwin F.: Woronin, Phytopath., $2: 1-4,1912 . \quad$ (Portrait.) 


\section{Zallinger, Johann Baptista}

Zallinger (Jean-Baptiste de Thurn). In, Biogr. Univers., 52 : 55, 56, 1828.

Poggendorff, S. C.: Zallinger zum Thurn. In, Biogr. Liter. Handwörterbuch, $2: 1390,1863$. 


\section{N D E X}

Adanson, 28

Brefeld, 80

America, rise and development of phytopathology in, 103

Bulliard, 41

Burdach, 32

American Phytopathological Society, establishment of, 110

Ancient era, 14

Anderson and Rankin, 115

Apple, bitter pit of, McAlpine on, 92

Arthur, 12, 67, 104

Atkinson, 104

BACTERIA and plant diseases, causal relation, discovery and establishment of, 66

Berkeley, 28, 55

Berlese, 97

Bibliography, 116-126

bibliographic, 118

biographic, 118

historic, 116

Bitter pit of apple, McAlpine on, 92

Blight, chestnut, epiphy totic of, 114 fire, Burrill on, 66 discovery of cause, 61 potato, De Bary on, 45

Blighting, Hesse on, 24 von Ehrenfels on, 29

Burrill, 61, 66, 104

Canker, Hales on, 30

Riedel on, 30

Schreger on, 31

von Ehrenfels on, 31

Carleton, 60

Cavara, 97

Chestnut blight, epiphytotic of, 114

Cleidemus, 15

Clement-Müllet, 20

Coler, 23

Columella, 18

Comes, 96

Copper, substitution of sulfur for, as fungicide, 112

Cordley, 112

Crops, disease-resistant, development of, 113

Crown gall, discovery of cause and nature, 109

Smith on, 109

DARK era, 20

Darwin, 43

De Bary, 45

De Candolle, 34, 41

De Tournefort, 26

Delacroix, 94

Disease-resistant crops, develop-

ment of, 113 
Dorrance, 12

Dorsett, 60

Dry rot of sugar beet, Frank on, 76

Entophytes, Unger on, 35

Entyloma Ranunculi, Ward on, 102

Epiphytotic of chestnut blight, 114

Era, Ancient, 14

Dark, 20

Middle, 20

Modern, 41

Premodern, 22

Present, 108

Eriksson, 85

Evils, secret, 23

Eysfarth, 26

Fabricius, 27

Fairchild, 60

Fire blight, Burrill on, 66 discovery of cause, 61

Forsyth, 30

Frank, 57, 75

Frankland, 42

Fungi, parasitic, Tulasne on, 41

GaLL, crown, discovery of cause and nature, 109

Smith on, 109

Galloway, 60, 104

Gnomonia erythrostoma, Frank on, 76

Greene, 15, 17

HALES, 30

Hallier, 54

Halstead, 105

Hartig, 57, 72

Hebraic period, 14

Hemeleia vastatrix, Ward on, 100

Hesse, 23

Hollyhock rust, Eriksson on, 88
Hort, 15

Hyacinths, yellow disease of, Burrill on, 61

IBN-AL-AWAM, 20

Istvanffi, 92

Jensen, 12,85

Jones, 43, 104

KIRCHNER, 77

Klebahn, 79

Küchenmeister, 42

Kühn, 26, 47

Kühnian period, 44

summary, 57

LAUREMBERG, 23

Léveillé, 41

Lily, Botrytis sp. of, Ward on, 102

Lind, 28

Link, 41

Linnæus, 25

Lutman, 104

MCALPINe, 91

Meyen, 37

Middle Era, 20

Millardet, 58, 63

Millardetian period, 58

Mixture, bordeaux, discovery of, by Millardet, 58, 63

Modern Era, 41

NiELSON, 85

$\Phi_{\text {RSTED }}, 54$

Orton, 114

Owen, 42

Parasitic fungi, Tulasne on, 41

Pasteur, 42, 45 
Pathogenetist school, 71 origin of, 44

Pathology, plant. See Phylopathology.

Period, Hebraic, 14

Kühnian, 44 summary, 57

Millardetian, 58

Plinian, 17

Renaissance, 22

Roman, 17

taxonomic, 25

Theophrastian, 14

Ungerian, 33

Zallingerian, 25

characteristic features, 32

Phoma betæ, Frank on, 76

Phylloxera, introduction into France, 65

Phytopathological Society, American, establishment of, 110

Phytopathology, 11 ancient era, 14 classification in, Fabricius', 27

Tournefort's, 26

Zallinger's, 28

Dark era, 20

establishment of chairs in universities, 109

Hebraic period, 14

Kühn's work on, synopsis of, 52

Kühnian period, 44

Millardetian period, 58

Modern era, 41

Plinian period, 17

Premodern era, 22

Present era, 108

Renaissance period, 22

rise and development of, in America, 59, 103

Theophrastian period, 14

Ungerian period, 33
Phytopathology, United States

Government sanction of, 62

Zallingerian period, 25

Phytophthora infestans, De Bary on, 45

Ward on, 102

Pierce, 60

Planchon, 65

Plant diseases, bacterial etiology, discovery of, 61

organisms of, Unger on, 35

Industry, United States Bureau of, founding of, 60

pathology. See Phytopathology.

Plants, physiology of death of,

Eysfarth's, 27

Plasmopara viticola, introduction

into France, 65

Plenck, 31

Plinian period, 17

Plinius Secundus, 17

Potato blight, De Bary on, 45

Predispositionist school, 71

Premodern era, 22

Present era, 108

Prillieux, 93

Puccinia graminis, Ward on, 102

Helianthi, Woronin on, 90

malvacearum, Eriksson on, 88

Quarantine Act of 1912, United States, 111

RANKIN and Anderson, 115

Ravn, 85

Ré, 12, 32

Reddick, 113

Renaissance period, 22

Riedel, 30

Roman period, 17

Rostrup, 81, 82

Rust, hollyhock, Eriksson on, 88 
Rust, Pliny on, 17

Theophrastus on, 15

Savastano, 20, 96

Schleiden, 34

Schreger, 31

Sclerotinia cinerea, Woronin on, 90 fructigena, Woronin on, 90

Scott, 112

Scribner, 59, 104

Secret evils, 23

Selby, 106

Siebold, 42

Smith, 60, 61, 104

Sorauer, 57,98

Sporodesmium exitosum, Kühn on, 48

Sprengel, 34

Steenstrup, 42

Stewart, 106, 113

Sugar-beet, dry rot of, Frank on, 76

Sulfur, substitution for copper as fungicide, 112

Swingle, 60

TAXonomic period, 25

Theophrastian period, 14

Theophrastus of Eresus, 15

Tree cement, Forsyth's, 30

Tulasne, 41
UNGER, 34

Ungerian period, 33 characteristic features, 40

United States Bureau of Plant Industry, founding of, 60

Government sanction of phytopathology, 62

Quarantine Act of 1912, 111

von Auersberg, 28

von Ehrenfels, 29, 31

von Liebig, 45

von Werneck, 32

WAITE, 60,67

Wakker, 61,68

Ward, 17, 88, 100

Webber, 60

Wiegmann, 36

Woods, 60

Woronin, 88

YeLLow disease of hyacinths, Burrill on, 61

ZALLINGER, 28

Zallingerian period, 25

characteristic features, 32 



\section{UNIVERSITY OF CALIFORNIA LIBRARY \\ Los Angeles}

This book is DUE on the last date stamped below.

Bomid. FEBMAD.

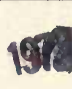

MAR 9 RECO

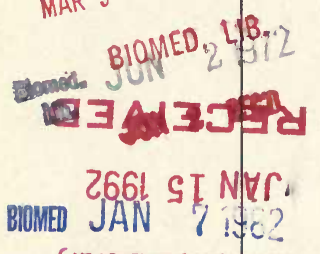

Rieıq! 7 les!pouio!g 
SB

731 whetzel -

w57o An outline

.? of the history of

phytopathology.

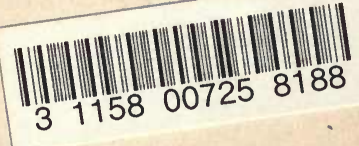

UC SOUTHERN REGIONAL LIBRARY FACILITY

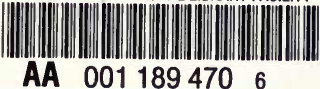

SB

731

W570

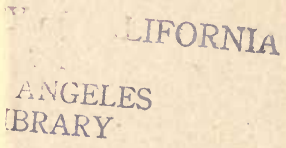


